\title{
Powder diffraction methods for studies of borohydride-based energy storage materials
}

\author{
Dorthe B. Ravnsbæk ${ }^{*, \text { I }}$, Yaroslav Filinchuk*, II, III, Radovan Černý*,IV and Torben R. Jensen*,I \\ I Center for Materials Crystallography $(C M C)$, Interdisciplinary Nanoscience Center (iNANO) and Department of Chemistry, Aarhus University, \\ Langelandsgade 140, 8000 Århus C, Denmark \\ II Swiss-Norwegian Beamlines at ESRF, BP-220, 38043 Grenoble, France \\ III Institute of Condensed Matter and Nanosciences, Université Catholique de Louvain, Place L. Pasteur 1, 1348 Louvain-la-Neuve, Belgium \\ Iv Laboratory of Crystallography, University of Geneva, 1211 Geneva, Switzerland
}

Received September 13, 2010; accepted October 9, 2010

Powder X-ray diffraction / Hydrogen storage /

Borohydrides / Structure analysis / Polymorphism

\begin{abstract}
The world today is facing increasing energy demands and a simultaneous demand for cleaner and more environmentally friendly energy technologies. Hydrogen is recognized as a possible renewable energy carrier, but its large-scale utilization is mainly hampered by insufficient hydrogen storage capabilities. In this scenario, powder diffraction has a central position as the most informative and versatile technique available in materials science. This is illustrated in the present review by synthesis, physical, chemical and structural characterisation of novel boron based hydrides for hydrogen storage. Numerous novel $\mathrm{BH}_{4}^{-}$based materials have been investigated during the past few years and this class of materials has a fascinating structural chemistry. The experimental methods presented can be applied to a variety of other materials.
\end{abstract}

\section{Introduction}

The sun is the primary energy source for the earth and the energy influx is 8000 times larger than the total human energy consumption (2008 values) (MacKay, 2009). Nature has converted sun-energy to chemical energy (biomass) during the past 2 billion years via photosynthesis and, since then, there has been storage of biomass in the crust of the earth. Biomass is slowly, over hundreds of millions of years, converted to carbohydrides, known as fossil fuels. Utilisation of fossil fuels forms the basis for development of the industrialised world, initiated in 1769 by James Watt's patent of his steam engine. This has lead to an extreme human energy consumption and we have burnt a large fraction of the available fossil fuels during the past only hundred years and will likely burn a major fraction of the remaining reserves during the coming only hundred years. The carbon dioxide level in the atmosphere

* Correspondence authors (e-mail addresses: inadr@inano.dk, yaroslav.filinchuk@esrf.fr, radovan.cerny@unige.ch, trj@chem.au.dk) has been oscillating between 180 to $280 \mathrm{ppm}$ within the past $\sim 420.000$ years (Petit et al., 1999), however, the use of fossil fuels undeniably increases $\mathrm{CO}_{2}$ concentrations in the atmosphere and in the surface of the oceans and today we are far off ancient times $\mathrm{CO}_{2}$ levels. Today we are facing $\mathrm{CO}_{2}$ concentrations of $390 \mathrm{ppm}$, which may increase further to $450-550 \mathrm{ppm}$ already in year 2030 and possibly $750 \mathrm{ppm}$ in year 2050 (International Energy Agency, 2008). Notice also, that this is caused by our cumulative $\mathrm{CO}_{2}$ production rather than our yearly, increasing $\mathrm{CO}_{2}$ production. This calls for abrupt and significant changes in our way of living rather than reduction in $\mathrm{CO}_{2}$ production by saving energy (MacKay, 2009). Unfortunately, there is today a close correlation between energy price and the economical growth and stability in the industrialised world, i.e. the western societies are strongly dependent on unlimited and cheap energy; fossil fuels.

An obvious carbon-free alternative to fossil fuels is renewable energy, e.g. from sun-, wind-, water-, wave-, geothermal-energy etc., which can generate either heat or electricity. Electricity, which is the other main energy carrier today beside carbohydrides, cannot be stored efficiently, so production and consumption have to be maintained in a very delicate balance (Eberle et al., 2009). Renewable energy is unevenly distributed both over time and geographically, therefore it must be stored in an efficient way. Further, most countries cannot rely on a single source of renewable energy, but need to combine several contributions, therefore a common energy carrier would facilitate integrations of the energy contributions and hydrogen is suggested as a possible future energy carrier. In this scenario hydrogen is produced from renewable energy, which can then be stored, transported and utilised at another place and time than where it was harvested. Water can be 'split' to oxygen and hydrogen either electrochemically from 'renewable' electricity or in the future maybe by direct photo catalytic water splitting (Kudo and Miseki, 2008). Hydrogen can then be efficiently converted electrochemically to electricity, heat and water as the only exhaust gas, using a fuel cell. Furthermore, hydrogen is nonpoisonous and forms (kinetically) stable compounds with 


\begin{tabular}{lccccl}
\hline $\begin{array}{l}\boldsymbol{M} \\
(\mathrm{g} / \mathrm{mol})\end{array}$ & $\begin{array}{c}\boldsymbol{\varrho}_{\boldsymbol{m}} \\
(\mathrm{wt} \%)\end{array}$ & $\begin{array}{c}\boldsymbol{\varrho}_{\boldsymbol{V}} \\
\left(\mathrm{g} \mathrm{H} \mathrm{H}_{2} / \mathrm{L}\right)\end{array}$ & $\begin{array}{c}\boldsymbol{T}_{\text {dec }} \\
(\mathrm{K})\end{array}$ & Ref. \\
\hline $\mathrm{TiFeH}_{\sim 2}$ & $\sim 105.73$ & $\sim 1.86$ & $\sim 101.7$ & 265 & Reilly and Wiswall, 1974 \\
$\mathrm{MgH}_{2}$ & 26.31 & 7.60 & 110.0 & 600 & Grochala and Edwards, 2004 \\
$\mathrm{LiAlH}_{4}$ & 37.95 & 10.6 & 74.0 & $>398$ & Züttel et al., 2003 \\
$\mathrm{LiBH}_{4}$ & 21.75 & 18.4 & 124.0 & $>650$ & Züttel et al., 2003 \\
$\mathrm{Al}\left(\mathrm{BH}_{4}\right)_{3}$ & 71.51 & 16.8 & 118.0 & $\sim 293^{a}$ & Schlesinger et al., 1953 \\
\hline
\end{tabular}

Table 1. Selected hydrides and their molar weight, $M$, gravimetric hydrogen content, $\varrho_{m}$, volumetric hydrogen content, $\varrho_{v}$ and decomposition temperature, $T_{\mathrm{dec}}$.

Notice the relation between volumetric $\left(\varrho_{V}\right)$, gravimetric $\left(\varrho_{m}\right)$ and material densities

$(\varrho): \varrho_{V}=\varrho_{m} \cdot \varrho$.

a: Slow decomposition at $\sim 293 \mathrm{~K}$.

oxygen. Hydrogen, the lightest element, has a huge gravimetric energy density of $120 \mathrm{MJ} / \mathrm{kg}$, approximately 3 times higher than gasoline. On the other hand, the volumetrically energy density is low due to low density both in the gas and liquid state of only 0.089 and $71 \mathrm{~g} / \mathrm{L}$, at 298 and $21 \mathrm{~K}$, respectively. Therefore, physical storage of hydrogen as a gas or liquid provide limited energy content and dense storage of hydrogen remain a major obstacle in order to create an efficient 'hydrogen-society'. However, solid state hydrogen storage has the potential to reach significantly higher hydrogen storage capacities, which are needed for mobile propulsion.

Historically, the interstitial metal hydrides formed by the heavier $d$ - and $f$-block metals have received significant interest because they store hydrogen reversibly. Unfortunately, the gravimetric hydrogen storage density is too low, e.g. $\varrho_{m}\left(\mathrm{TiFeH}_{\sim 2}\right)=1.86 \mathrm{wt} \%$, see Table 1. Simultaneously, the abundant and cheap metal, magnesium was investigated due to high gravimetric hydrogen storage density of $\varrho_{m}\left(\mathrm{MgH}_{2}\right)=7.6 \mathrm{wt} \%$. Unfortunately, due to unfavourable thermodynamic properties, $\Delta H_{f}=75 \mathrm{~kJ} / \mathrm{mol} \mathrm{H}_{2}$, bulk $\mathrm{MgH}_{2}$ must be heated to $600 \mathrm{~K}$ in order to release hydrogen at $p\left(\mathrm{H}_{2}\right)=1$ bar. However, significant improvements in kinetic properties are observed for ball-milled samples of $\mathrm{Mg} / \mathrm{MgH}_{2}$ with $\mathrm{V}_{2} \mathrm{O}_{5}$ or $\mathrm{Nb}_{2} \mathrm{O}_{5}$ (Dornheim et al., 2007) and thermodynamic properties may be changed by alloying the $\mathrm{Mg} / \mathrm{MgH}_{2}$ system (Andreasen et al., 2006; Andreasen et al., 2005). This may allow practical utilisation under more moderate conditions. Experimental studies have shown that the thermodynamic properties are more favourable for nano particles $(\sim 5 \mathrm{~nm})$ (Paskevicius, Sheppard and Buckley, 2010) and nanoconfinement have been shown to improve the reversibility, stability, kinetics, and possibly also the thermodynamic properties of chemical reactions involved in reversible release and uptake of hydrogen (Nielsen et al., 2009; Nielsen et al., 2010).

Bogdanović and Schwickardi, 1997 showed that $\mathrm{NaAlH}_{4}$ can reversible store hydrogen at more moderate conditions by doping with titanium compounds. One of the most frequently used additives is $\mathrm{TiCl}_{3}$ but other $d$ - and $f$-block metals have similar properties. This observation introduced a paradigm shift within the research field of 'hydrogen storage materials'. Covalently bonded hydrogen in complex aluminium and boron based hydrides has been revisited during the past decade (Schlesinger and Burg, 1942; Marks and Kolb, 1977) and notably the lighter borohydrides have received significant attention during the past few years (Grochala and Edwards, 2004). Table 1 illustrates that borohydrides can have extreme hydrogen contents, but unfortunately, thermodynamic and kinetic properties are insufficient for practical applications. Lithium borohydride, $\mathrm{LiBH}_{4}$ has an extreme gravimetric hydrogen content of $\varrho_{m}=18.5 \mathrm{wt} \%$. However, the use of $\mathrm{LiBH}_{4}$ as a solid-state hydrogen storage material is hampered by the unfavourable high thermal stability; that is, release of $\mathrm{H}_{2}$ takes place at temperatures above $670 \mathrm{~K}$ and, importantly, uptake of $\mathrm{H}_{2}$ only occurs under extreme conditions.

Numerous unsolved problems remain on our way towards a sustainable, carbon free energy system based on renewable energy and hydrogen as a future energy carrier. Novel materials form the back-bone in most emerging energy related technologies. Here we review the recent progress in synthesis and characterization of structure and reactivity of novel boron based light hydrides achieved with the help of powder diffraction. The use of powder diffraction in materials science is a powerful tool that may essentially bring us to a sustainable, carbon free future.

\section{Methods}

\section{Mechanochemistry}

During the past decades mechanochemistry, such as ball milling has become increasingly important, and the majority of novel metal borohydrides are synthesized by this solvent-free method (Suryanarayana, 2001, Balema et al., 2002). Reactant composition and pressure obtained by collision between balls and container wall are of major importance, in particular for high-energy ball milling, in contrast to the solution-based techniques, which are mainly temperature 'driven' (Hagemann and Černý, 2010a).

This preparation method yields fine powders, which are often a mixture of several known and unknown compounds. Powder X-ray diffraction is a very powerful tool to identify and structurally characterize the reaction pathways, intermediates and reaction products. A variety of reactions can occur and in some cases several competing reactions are observed simultaneously. Metathesis, or double substitution reaction, is a well known mechanism for chemical reactions during ball milling, yielding a metal borohydride and a metal chloride as a byproduct. However, often bimetallic borohydrides are formed via more complex chemical reactions (Hagemann et al., 2008, Ravnsbæk et al., 2009, Černý et al., 2010a, b), possibly by a combination of metathesis and addition reactions, see Eqs. (1) and 
(2) (Ravnsbæk et al., 2009).

$$
\begin{aligned}
& 2 \mathrm{ZnCl}_{2}+5 \mathrm{NaBH}_{4} \rightarrow \mathrm{NaZn}_{2}\left(\mathrm{BH}_{4}\right)_{5}+4 \mathrm{NaCl}, \\
& \mathrm{ZnCl}_{2}+3 \mathrm{NaBH}_{4} \rightarrow \mathrm{NaZn}\left(\mathrm{BH}_{4}\right)_{3}+2 \mathrm{NaCl} .
\end{aligned}
$$

The reactions observed within the Zn-containing systems, involving $\mathrm{ZnCl}_{2}-\mathrm{MBH}_{4}$ reactants, illustrate that small deviations in the composition of reactants may lead to significantly different reaction products and shows that it is crucial to perform ball-milling of starting mixtures in several different ratios (Ravnsbæk et al., 2009; Černý et al., 2010c). The variation of relative Bragg peak intensities in ball-milled samples with different mixture ratios may provide information about the composition of new compounds. A reliable estimate of the composition of new compounds may be a crucial information facilitating structural solution from PXD data (Černý et al., 2010c).

Furthermore, mixed-cation mixed-anion borohydrides can be prepared via addition reactions, e.g. ball milling a mixture of $\mathrm{ZnCl}_{2}-\mathrm{KBH}_{4}(1: 1)$ leads to a phase pure product, of $\mathrm{KZn}\left(\mathrm{BH}_{4}\right) \mathrm{Cl}_{2}$ (Ravnsbæk et al., 2010a).

Side reactions can also take place involving either one of the reactants and the metal chlorides formed as a byproduct during formation of the novel borohydrides (see Eqs. (1) and (2). This can lead to formation of ternary metal chlorides by addition reactions, e.g. for the zinc based system $\mathrm{ZnX} X_{2}-\mathrm{MBH}_{4}, X=\mathrm{Cl}$ or $\mathrm{Br}$ and $M=\mathrm{Li}, \mathrm{Na}$ or K (Ravnsbæk et al., 2009).

$$
\mathrm{ZnX}_{2}+2 M X \rightarrow M_{2} \mathrm{ZnX}{ }_{4}
$$

The reaction shown in Eq. (3) has increasing dominance for heavier elements: $\mathrm{Na}, \mathrm{K}>\mathrm{Li}, \mathrm{Br}>\mathrm{Cl}$, but Eq. (3) is only weakly coupled with the formation of the borohydrides. In other words, reaction Eqs. (1) and (2) are faster than reaction Eq. (3). This is in contrast to the system $\mathrm{ScCl}_{3}-M \mathrm{BH}_{4}, \quad M=\mathrm{Na}$ or $\mathrm{K}$, which yields $M \mathrm{Sc}\left(\mathrm{BH}_{4}\right)_{4}$ without any detectable diffraction from $M \mathrm{Cl}$, owing to a fast formation of $M_{3} \mathrm{ScCl}_{6}$ via an addition reaction similar to eq. 3 (Černý et al., 2010a, b). These observations suggest that the formation of $M_{3} \mathrm{ScCl}_{6}$ is much faster than the formation of $M \mathrm{Sc}\left(\mathrm{BH}_{4}\right)_{4}$ and the overall reaction for the $\mathrm{ScCl}_{3}-\mathrm{NaBH}_{4}$ 1:2 ratio is described in Eq. (4), which leads to the maximal borohydride yield of $22 \mathrm{wt} \%$.

$$
2 \mathrm{ScCl}_{3}+4 \mathrm{NaBH}_{4} \rightarrow \mathrm{NaSc}\left(\mathrm{BH}_{4}\right)_{4}+\mathrm{Na}_{3} \mathrm{ScCl}_{6} \text {. }
$$

Ball milling can also facilitate formation of solid solutions as well known for alloying of metals, e.g. lithium borohydride may dissolve $\sim 10 \%$ lithium chloride as described in Eq. (5) (Arnbjerg et al., 2009).

$$
x \mathrm{LiCl}+(1-x) \mathrm{LiBH}_{4} \rightarrow \mathrm{Li}\left(\mathrm{BH}_{4}\right)_{1-x} \mathrm{Cl}_{x} .
$$

This type of reaction can also take place for other alkali borohydrides, e.g. $\mathrm{NaBH}_{4}-\mathrm{NaCl}$ (Ravnsbæk et al., 2010d).

\section{In situ synchrotron radiation powder X-ray diffraction (SR-PXD)}

The analysis of the ball-milled products is typically done by powder X-ray diffraction (PXD), in conjunction with spectroscopic methods like Raman, infrared and NMR spectroscopy as well as thermal desorption studies. For the metal borohydrides hydrogen desorption reactions are typically associated with significant changes in both composition and structure. Furthermore, solid crystalline materials are involved in reactions during hydrogen release and uptake from most known solid hydrides. Therefore, even though hydrogen has the lowest X-ray scattering power of any element, one can clearly observe hydrogen absorption and desorption as structural changes (Hauback, 2008; Gray, Cookson and Blach, 2006; Orimo et al., 2007).

In order to collect PXD diffraction data as a function of the thermal decomposition it is necessary to perform in situ time- and temperature-resolved experiments. X-ray scattering typically requires a shorter data acquisition time compared to neutron diffraction and is therefore more amenable both to study fast reactions involving metastable compounds and intermediate decomposition products and also for kinetic studies of hydrogen absorption and desorption. Thin-walled glass capillaries commonly used as sample holders give a relatively high amorphous background and react with some borohydrides at elevated temperatures. Single-crystal sapphire capillaries are an option to remove both undesired effects. Strong diffraction spots from the sapphire should be masked when using 2D detectors.

We have developed sample cells for in situ diffraction studies under variable gas pressure and temperature. One cell is based on a single-crystal sapphire $\left(\mathrm{Al}_{2} \mathrm{O}_{3}\right)$ capillary, which allows for measurements under gas pressure of up to 300 bar. Since the gas pressure is simultaneously applied to both ends of the sample, it allows fast change of pressure by 3-4 orders of magnitude within a few seconds. The temperature is measured by a thermocouple, placed inside the sapphire capillary $c a .1 \mathrm{~mm}$ from the sample and the sample cell can be operated at extreme temperatures, in principle up to the melting point of $\mathrm{Al}_{2} \mathrm{O}_{3}$ at $2053 \mathrm{~K}$ (Chupas et al., 2008, Jensen et al., 2010).

Another cell employs standard commercial thin-walled glass or quartz capillaries and is used at lower pressures up to 100 bar and typically in the temperature range 80 to $500 \mathrm{~K}$, in principle up to the melting point of $\mathrm{SiO}_{2}$ at $1920 \mathrm{~K}$ (Clausen et al., 1991; Norby et al., 1997; Jensen et al., 2010). Both sample cells are fast and easy to use, can be handled under inert conditions in a glove box and allow collecting high quality powder and single-crystal diffraction data.

There are a few specific recommendations for collecting diffraction data on light hydrides under high pressure. Most interesting transitions occur at moderate pressure of less than $20 \mathrm{GPa}$. This allows use of large holes in gaskets, thus illuminating by the X-ray beam a large sample volume and collecting data suitable for structure solution. Also in this pressure range borohydrides provide relatively good hydrostatic conditions without any pressure transmitting medium. Substances composed of the light elements give a weak diffraction signal and therefore a lower than usual signal-to-background ratio. The signal is even weaker for small samples contained in a diamond anvil cell (DAC). Area detectors accumulate extremely high total intensity, thus reducing impact of statistical noise and providing a good time resolution. However, a long exposure time of $>10 \mathrm{~min}$. may be necessary to obtain good statistics for the high-angle peaks. For that, the low-background image plate detectors have an advantage over the CCDs. 

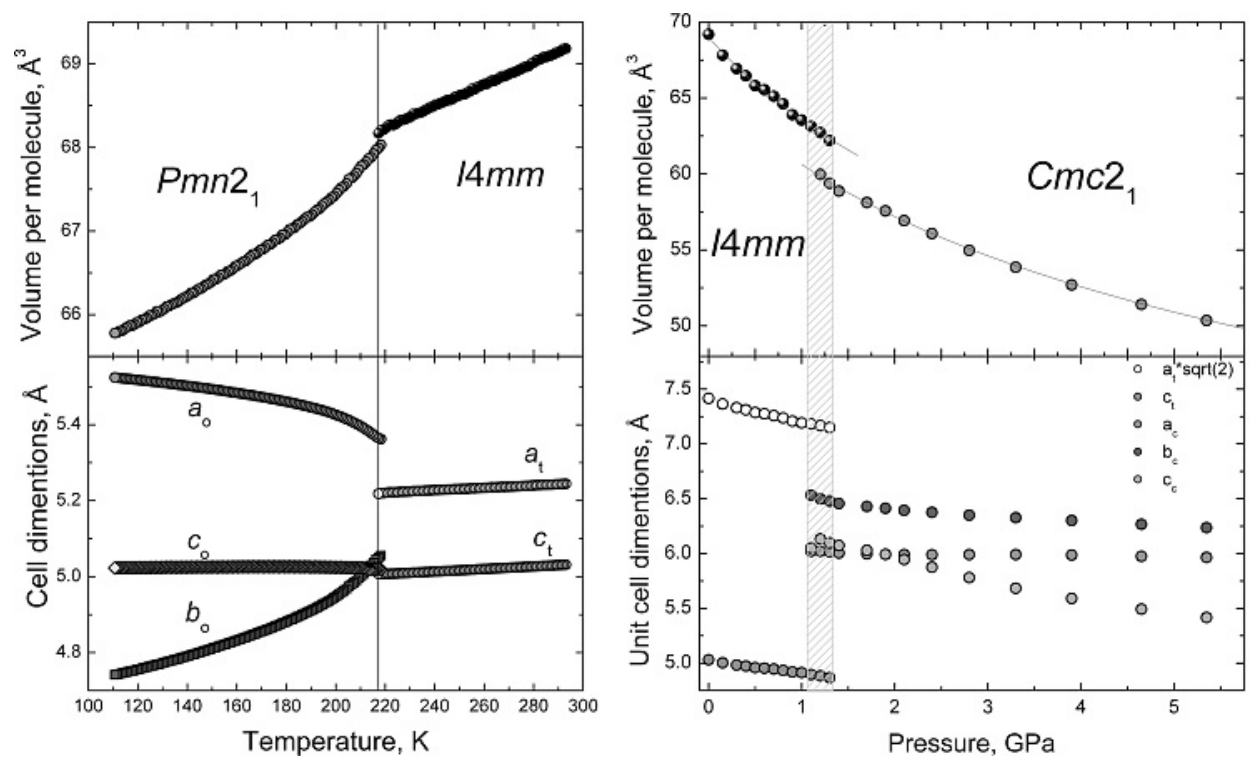

Fig. 1. Variation of the molecular volume and unit cell dimensions of ammonia borane, $\mathrm{NH}_{3} \mathrm{BH}_{3}$, as a function of temperature and pressure (Filinchuk et al., 2009a). The circles represent experimental data, and the lines are the best fits to the Murnaghan equation of state (right panel).
A combined use of the temperature- and pressure-induced evolution of crystal structures and their polymorphic transformations is a way to reveal the interactions responsible in particular for the hydrogen storage properties. A power of the in-situ powder diffraction at a synchrotron source can be illustrated by an example of ammonia borane, $\mathrm{NH}_{3} \mathrm{BH}_{3}$, a compound containing $19.5 \mathrm{wt} \%$ of hydrogen (Fig. 1). High data quality allowed for solving the crystal structure, identify the structural distortions and propose a generic $p-T$ phase diagram (Filinchuk et al., 2009a).

\section{Ab-initio structure determination}

The diffraction methods for structural characterization of metal hydrides have recently been reviewed by Černý, 2008. In the case of lightweight hydrides, hydrogen becomes a non-negligible X-ray scatterer, i.e. for $\mathrm{LiBH}_{4}$ hydrogen atoms have been located unambiguously by PXD alone (Soulié et al., 2002). Although the precision of the metal-hydrogen bond lengths obtained from PXD data are lower than usually attained by neutron diffraction. The positions of $\mathrm{H}$-atoms determined from X-ray diffraction data must be displaced from $\mathrm{B}$-atom along the $\mathrm{B}-\mathrm{H}$ bond by $\sim 0.08 \AA$ due to the displacement of the electron cloud, and by $\sim 0.034-0.10 \AA$ due to the libration motion of $\mathrm{BH}_{4}$ groups, which is both temperature and structure dependent (Filinchuk et al., 2008a). The synchrotron X-ray diffraction is nowadays routinely used to study light metal borohydrides (Filinchuk et al., 2010a), typically using an area detector and a Debye-Scherrer geometry. The advantage of this setup is the simple sample environment and fast data collection, which allows in-situ studies, high data collection rates, excellent time resolution, highly accurate measurements of diffracted intensities (good powder average), and a lower sensitivity to preferred orientation effects. A combination of high counting rates with excellent reciprocal space resolution provided by curved solid state detectors (Mozzanica et al., 2009) allows even more complex structures to be studied in-situ.

The bottle-neck of the ab-initio structural studies of new compounds is indexing of the powder pattern, which is extremely challenging for multiphase samples prepared by ball milling. A successful strategy consists of the socalled 'decomposition-aided indexing', which utilizes insitu diffraction as a function of the temperature ( $T$-ramping) up to the decomposition temperature of different phases. This procedure allows to separate diffraction peaks of individual phases illustrated in Fig. 2 by SR-PXD for a ball milled $\mathrm{KBH}_{4}-\mathrm{ScCl}_{3}$ mixtures (Černý et al., 2010b). In this system a ball-milled sample contains two new phases, $\mathrm{KSc}\left(\mathrm{BH}_{4}\right)_{4}, \mathrm{~K}_{3} \mathrm{ScCl}_{6}$ and non-reacted $\mathrm{KBH}_{4}$. Only $T$-ramping has allowed the assignment of observed peaks to individual phases, and led to a successful indexing of powder patterns. Useful guidelines for successful indexing can be found in (David and Shankland, 2008, Černý and Favre-Nicolin, 2007).

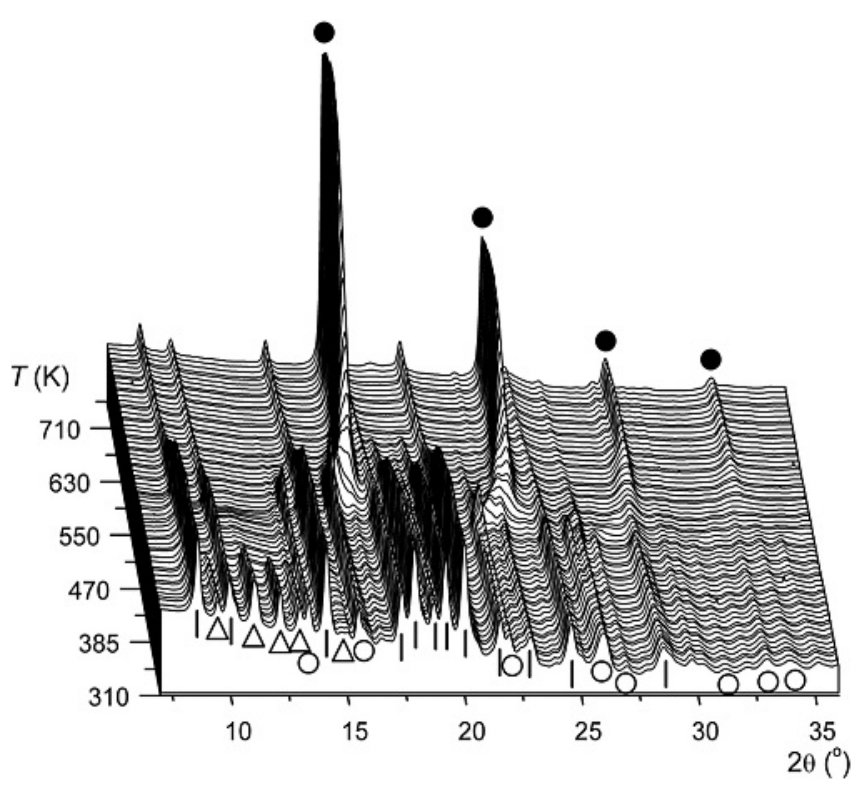

Fig. 2. In situ synchrotron radiation $\mathrm{X}$-ray powder diffraction data for a ball milled sample of $\mathrm{KBH}_{4}-\mathrm{ScCl}_{3}(2: 1)(R T$ to $580 \mathrm{~K}, \Delta T / \Delta t=5 \mathrm{~K} / \mathrm{min}$, $\lambda=0.9707 \AA$ ). Only utilization of $T$-ramping allowed for determination of attribution of observed peaks to individual phases, $\mathrm{KSc}\left(\mathrm{BH}_{4}\right)_{4}$ and $\mathrm{K}_{3} \mathrm{ScCl}_{6}$, and led to a successful indexing of powder patterns (Černý et al., 2010b). Symbols: $\triangle \mathrm{KSc}\left(\mathrm{BH}_{4}\right)_{4}, \mid \mathrm{K}_{3} \mathrm{ScCl}_{6}, \bigcirc \mathrm{KBH}_{4}$ and $\bullet \mathrm{KCl}$. 
Space group determination can be another critical point: "While observing lattice-centering extinctions is usually relatively easy, the determination of the correct space group symmetry elements is generally more challenging" (David and Shankland, 2008). This is even more valid for poorly crystallized hydrides with broad peaks and strong pseudosymmetry, which is difficult to detect in the X-ray pattern due to weak X-ray scattering power of hydrogen.

Crystal structures of light metal hydrides may be solved either by reciprocal or direct space methods (Černý, 2008). An excellent example is $\mathrm{Mg}\left(\mathrm{BH}_{4}\right)_{2}$, which is a complex structure solved independently by both methods (Černý et al., 2007; Her et al., 2007). The most popular direct space program in the "hydride world" is Fox (Favre-Nicoline and Černý, 2002). The complexity of the structures solved by this program ranges from 2 to 55 independent atoms. Guidelines for efficient use of Fox can be found in Černý and Favre-Nicolin, 2007.

Refinement of the final structural model against powder data is done by the Rietveld method. For details of the method and for guidelines, see McCusker et al., 1999. Two programs are often used: FullProf (Rodríguez-Carvajal, 1993) and TOPAS (Coelho, 2004). Both allow for joint refinement of several powder patterns, rigid body modeling, anisotropic line broadening modeling (even if not often observed in borohydrides) and so-called sequential refinement, i.e. refinement of many powder patterns as a function of temperature, pressure etc.

Typically the structures of borohydrides are solved and refined with the $\mathrm{BH}_{4}$ groups as semi-rigid ideal tetrahedra with one common refined $\mathrm{B}-\mathrm{H}$ distance. For the $\mathrm{BH}_{4}$ groups situated on a symmetry element the $\mathrm{BH}_{4}$ tetrahedra are allowed only to translate and to rotate following the operations of the symmetry element. The anti-bump distance restraints are usually needed to stabilize the refinement. However, examples of restraint-free refinement are known (Černý et al., 2010a). The displacement parameters are refined isotropically. For rigid body refinement the uncertainties of crystallographic coordinates of hydrogen atoms are usually not available from the least squares matrix, and can be estimated by the bootstrap method (Efron and Tibshirani, 1986). The high values of $\chi^{2}$ often observed reflect mainly the extremely high counting statistics of the powder diffraction data obtained from modern solid state detectors.

High-pressure phases may show a pronounced preferred orientation of crystallites with respect to the compression direction, as observed e.g. for the cubic and tetragonal phases of $\mathrm{NaBH}_{4}$ (Filinchuk et al., 2007; Chernyshov et al., 2008) and in case of the strong texture it may prevent solving a crystal structure. Therefore it might be essential to model the texture by including one parameter in the global optimization by direct space methods and testing plausible directions of the preferred orientation. For more details specific to the treatment of the high-pressure diffraction data on metal hydrides see Filinchuk, 2010.

A post-experimental DFT-optimization helps to validate new structures, locate light hydrogen atoms, especially when using high-pressure diffraction data (Filinchuk et al., 2008c; Filinchuk et al., 2009a), and even correct the symmetry and some structural details (Dai et al., 2008, Fi- linchuk et al., 2009b; Lindemann et al., 2010). In some cases it allows to achieve a global minimum in a Rietveld refinement and thus can be highly recommended for the systems containing so light elements as hydrogen.

\section{Mono- and bimetallic borohydrides and anion-substituted derivatives}

The past few years have seen a significant increase in the number of new borohydrides and of experimental and theoretical studies on their structural and solid-state chemistry. The investigations have been summarized in several recent reviews on crystal structures (Filinchuk et al., 2008b; Filinchuk et al., 2010a), physical properties (Orimo et al., 2007; Sundqvist and Andersson, 2009) and phase relations at different $p-T$ conditions (Sundqvist, 2009). In this chapter we review the experimentally determined crystal structures of metal borohydrides, summarized by their crystallographic characteristics in Table 2 , with a reference to the most accurate structural study. Most structures were determined and polymorphic transformation detected by synchrotron X-ray powder diffraction.

The alkali metal borohydrides exhibit dominantly ionic character in the $M-\mathrm{BH}_{4}$ coordination, mainly due to low electronegativity of the metal leading to an almost complete charge transfer from the metal to the $\mathrm{BH}_{4}$ group. However, the intensive structural studies during the past couple of years of borohydrides based on the alkaline earth and transition metals have revealed directionality and some degree of covalency in the $M-\mathrm{BH}_{4}$ interaction. This observation may be attributed to higher electronegativity, causing smaller charge transfer from the metal atom to the $\mathrm{BH}_{4}$ group and associated destabilization of this unit. Thus, the metal borohydrides can roughly be subdivided into two groups: one with the more stable compounds with predominantly ionic character and another group of the less stable compounds exhibiting strong directionality and partly covalency in the $M-\mathrm{BH}_{4}$ bonding.

Furthermore, a number of borohydride compounds containing halide anions have been investigated, e.g. mixed-cation mixed-anion borohydrides or solid solutions of alkali borohydride-alkali halide systems. These materials are treated as a separate class of derivatives of metal borohydrides.

\section{Borohydrides with dominantly ionic $M-\mathrm{BH}_{4}$ bonding}

LiBH$_{4}$. Four phases of $\mathrm{LiBH}_{4}$ are known: two at ambient (Fig. 3a, b) and two at high pressure (Fig. 3c, d). Structures of the ambient pressure polymorphs were studied using synchrotron powder diffraction by Soulié et al., 2002. The low-temperature Pnma structure transforms into the wurtzite-like high-temperature phase at $\sim 380 \mathrm{~K}$. More detailed studies by neutron powder diffraction on the isotropically substituted ${ }^{7} \mathrm{Li}^{11} \mathrm{BD}_{4}$ (Hartman et al., 2007) and by synchrotron diffraction on single crystals and powders (Filinchuk et al., 2008a) show that the $\mathrm{BH}_{4}$ groups in these two phases have a nearly ideal tetrahedral geometry and reveal large and anisotropic displacements for hydrogen atoms in the $P 6_{3} m c$ phase (Fig. $3 b$ ). An entropy contribution from the disorder is considered as a factor stabi- 
Table 2. Known phases of metal borohydrides and their crystallographic characteristics. Ambient pressure and temperature is assumed if not otherwise specified.

\begin{tabular}{|c|c|c|c|c|c|c|c|}
\hline Compound & Sp. gr. & $a(\AA)$ & $b(\AA)$ & $c(\AA)$ & $\beta\left({ }^{\circ}\right)$ & $p, T$ & Ref. \\
\hline \multirow[t]{4}{*}{$\mathrm{LiBH}_{4}$} & Pnma & $7.17858(4)$ & $4.43686(2)$ & $6.80321(4)$ & & & Soulié et al., 2002 \\
\hline & $P 6_{3} m c$ & $4.27631(5)$ & & $6.94844(8)$ & & $408 \mathrm{~K}$ & Soulié et al., 2002 \\
\hline & $A m a 2$ & $6.4494(9)$ & $5.307(1)$ & $5.2919(9)$ & & $2.4 \mathrm{GPa}$ & Filinchuk et al., 2008c \\
\hline & $F m \overline{3} m$ & $5.109(2)$ & & & & $18.1 \mathrm{GPa}$ & Filinchuk et al., 2008c \\
\hline \multirow[t]{3}{*}{$\mathrm{NaBH}_{4}$} & $F m \overline{3} m$ & $6.1308(1)$ & & & & $200 \mathrm{~K}$ & Filinchuk, Hagemann, 2008 \\
\hline & $P 4_{2} / n m c$ & $4.37062(4)$ & & $5.95094(9)$ & & $180 \mathrm{~K}$ & Babanova et al., 2010 \\
\hline & Pnma & $7.297(1)$ & $4.1166(5)$ & $5.5692(7)$ & & $11.2 \mathrm{GPa}$ & Filinchuk et al., 2007 \\
\hline \multirow[t]{2}{*}{$\mathrm{KBH}_{4}$} & $F m \overline{3} m$ & $6.728(1)$ & & & & & Luck, Schelter, 1999 \\
\hline & $P 4_{2} / n m c$ & $4.7004(2)$ & & $6.5979(3)$ & & $10 \mathrm{~K}$ & Renaudin et al., 2004 \\
\hline \multirow[t]{4}{*}{$\mathrm{RbBH}_{4}$} & $F m \overline{3} m$ & $7.0293(1)$ & & & & & Renaudin et al., 2004 \\
\hline & P4/nmm & $5.6122(1)$ & & $4.0887(1)$ & & $5.5 \mathrm{GPa}$ & Filinchuk et al., 2010b \\
\hline & $C 222$ & $5.3679(6)$ & $5.134(1)$ & $3.9098(3)$ & & $16.1 \mathrm{GPa}$ & Filinchuk et al., 2010b \\
\hline & $I \overline{4} 2 m$ & $5.0057(7)$ & & $7.816(1)$ & & $23.5 \mathrm{GPa}$ & Filinchuk et al., 2010b \\
\hline $\mathrm{Be}\left(\mathrm{BH}_{4}\right)_{2}$ & $I 4_{1} c d$ & $13.62(1)$ & & $9.10(1)$ & & & Marynick, Lipscomb, 1972 \\
\hline \multirow{2}{*}{$\operatorname{Mg}\left(\mathrm{BH}_{4}\right)_{2}$} & $P 6_{1} 22$ & $10.354(1)$ & & $37.055(4)$ & & $100 \mathrm{~K}$ & Filinchuk et al., 2009b \\
\hline & Fddd & $37.072(1)$ & $18.6476(6)$ & $10.9123(3)$ & & & Her et al., 2007 \\
\hline \multirow[t]{4}{*}{$\mathrm{Ca}\left(\mathrm{BH}_{4}\right)_{2}$} & $F 2 d d$ & $8.7759(3)$ & $13.0234(4)$ & $7.4132(2)$ & & $91 \mathrm{~K}$ & Filinchuk et al., 2009c \\
\hline & $P 4_{2} / m$ & $6.9468(1)$ & & $4.3661(1)$ & & $480 \mathrm{~K}$ & Buchter et al., 2008 \\
\hline & $I \overline{4} 2 d$ & $5.8446(3)$ & & $13.228(1)$ & & $495 \mathrm{~K}$ & Filinchuk et al., 2009c \\
\hline & $P b c a$ & $13.0584(8)$ & $8.3881(4)$ & $7.5107(4)$ & & $300 \mathrm{~K}$ & Buchter et al., 2009 \\
\hline $\mathrm{Mn}\left(\mathrm{BH}_{4}\right)_{2}$ & $P 3_{1} 12$ & $10.435(1)$ & & $10.835(2)$ & & & Černý et al., 2009 \\
\hline \multirow[t]{2}{*}{$\mathrm{Al}\left(\mathrm{BH}_{4}\right)_{3}$} & $C 2 / c$ & $21.917(4)$ & $5.986(1)$ & 21.787(4) & $111.90(3)$ & $150 \mathrm{~K}$ & Aldridge et al., 1997 \\
\hline & $P n a 2_{1}$ & $18.021(3)$ & $6.138(2)$ & $6.199(1)$ & & $195 \mathrm{~K}$ & Aldridge et al., 1997 \\
\hline \multirow[t]{2}{*}{$\mathrm{Y}\left(\mathrm{BH}_{4}\right)_{3}$} & $\operatorname{Pa} \overline{3}$ & $10.7445(4)$ & & & & & Sato et al., 2008 \\
\hline & $F m \overline{3} c$ & $11.0086(1)$ & & & & & Frommen et al., 2010 \\
\hline $\mathrm{LiK}\left(\mathrm{BH}_{4}\right)_{2}$ & Pnma & $7.91337(5)$ & $4.49067(3)$ & $13.8440(1)$ & & & Nickels et al., 2008 \\
\hline $\mathrm{LiSc}\left(\mathrm{BH}_{4}\right)_{4}$ & $P \overline{4} 2 c$ & $6.07593(6)$ & & $12.0338(1)$ & & & Hagemann et al., 2008 \\
\hline $\mathrm{NaSc}\left(\mathrm{BH}_{4}\right)_{4}$ & $\mathrm{Cmcm}$ & $8.170(2)$ & $11.875(3)$ & $9.018(2)$ & & & Černý et al., 2010a \\
\hline $\mathrm{KSc}\left(\mathrm{BH}_{4}\right)_{4}$ & Pnma & $11.856(5)$ & $7.800(3)$ & $10.126(6)$ & & & Černý et al., 2010b \\
\hline $\mathrm{LiZn}_{2}\left(\mathrm{BH}_{4}\right)_{5}$ & Cmca & $8.6244(3)$ & $17.8970(8)$ & $15.4114(8)$ & & & Ravnsbæk et al., 2009a \\
\hline $\mathrm{NaZn}_{2}\left(\mathrm{BH}_{4}\right)_{5}$ & $P 2_{1} / c$ & $9.397(2)$ & $16.635(3)$ & $9.136(2)$ & $112.66(2)$ & & Ravnsbæk et al., 2009a \\
\hline $\mathrm{NaZn}\left(\mathrm{BH}_{4}\right)_{3}$ & $P 2_{1} / c$ & $8.2714(16)$ & $4.5240(7)$ & $18.757(3)$ & $101.69(1)$ & & Ravnsbæk et al., 2009a \\
\hline $\mathrm{Li}_{4} \mathrm{Al}_{3}\left(\mathrm{BH}_{4}\right)_{13}$ & $P \overline{4} 3 n$ & $11.3640(3)$ & & & & $101 \mathrm{~K}$ & Lindemann et al., 2010 \\
\hline $\mathrm{KZn}\left(\mathrm{BH}_{4}\right) \mathrm{Cl}_{2}$ & $P 2_{1} / m$ & 7.6257(9) & $5.7375(6)$ & $6.8786(9)$ & $97.79(2)$ & & Ravnsbæk et al., 2010a \\
\hline $\mathrm{NaY}\left(\mathrm{BH}_{4}\right)_{2} \mathrm{Cl}_{2}$ & $P 2 / a$ & $6.8114(5)$ & $8.2051(7)$ & $6.6654(5)$ & $89.96(1)$ & $500 \mathrm{~K}$ & Ravnsbæk et al., 2010b \\
\hline $\mathrm{Li}\left(\mathrm{BH}_{4}\right)_{0.7} \mathrm{Cl}_{0.3}$ & Pnma & $7.001(1)$ & $4.3236(9)$ & $6.808(1)$ & & & Arnbjerg et al., 2009 \\
\hline $\mathrm{Ca}\left(\mathrm{BH}_{4}\right)_{1.4} \mathrm{I}_{0.6}$ & $P \overline{3} m 1$ & $4.311(1)$ & & $6.867(2)$ & & $300 \mathrm{~K}$ & Rude et al., 2010 \\
\hline $\mathrm{Ca}\left(\mathrm{BH}_{4}\right)_{1.3} \mathrm{I}_{0.7}$ & Pnnm & $7.271(2)$ & $7.0418(1)$ & $4.4600(6)$ & & $600 \mathrm{~K}$ & Rude et al., 2010 \\
\hline $\mathrm{Ca}\left(\mathrm{BH}_{4}\right)_{0.8} \mathrm{I}_{1.2}$ & $I 4 m m$ & $4.1067(2)$ & & $24.821(2)$ & & $618 \mathrm{~K}$ & Rude et al., 2010 \\
\hline $\mathrm{Mg}_{1-x} \mathrm{Mn}_{x}\left(\mathrm{BH}_{4}\right)_{2}$ & $P 3_{1} 12$ & $\begin{array}{l}10.3586- \\
10.3911(3)\end{array}$ & & $\begin{array}{l}10.8357- \\
10.8180(5)\end{array}$ & & & Černý et al., 2010d \\
\hline
\end{tabular}

lizing the hexagonal structure (Filinchuk et al., 2008a), which shows superionic conductivity (Matsuo et al., 2007). At room temperature and 1.2-10 GPa pressures, a phase with a pseudo-tetragonal Ama2 structure containing the $\mathrm{BH}_{4}$ group in a novel square-planar coordination by four $\mathrm{Li}$ atoms forms (Filinchuk et al., 2008c). Above $10 \mathrm{GPa}$ another $\mathrm{LiBH}_{4}$ phase appears (Filinchuk et al., 2008c), isostructural to the cubic $\mathrm{NaBH}_{4}$.

Combination of volumetric (Pistorius, 1974) and synchrotron X-ray powder diffraction (Dmitriev et al., 2008) studies were used to map the $p$ - $T$ diagram (Fig. 4) and follow structural evolution of the polymorphs. Existence of cation-anion layers in all four $\mathrm{LiBH}_{4}$ phases are suggested from the phenomenological analysis of mechanisms of phase transitions (Dmitriev et al., 2008). It has been shown that the order parameter in $\mathrm{LiBH}_{4}$ can be parameterized as a shift of layers formed by $\mathrm{Li}$ and $\mathrm{BH}_{4}$, together with in-layer deformations. Cation-anion layers can easily be identified in the hexagonal phase, with three short $\mathrm{Li}-\mathrm{B}$ contacts in the basal plane and a long one parallel 


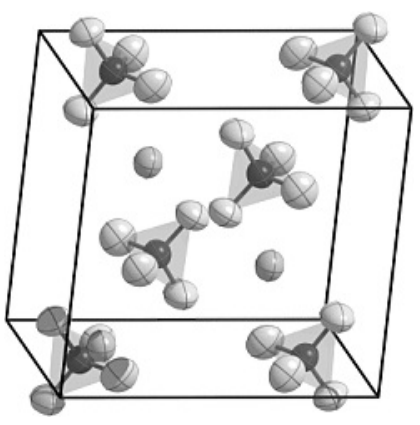

(a)

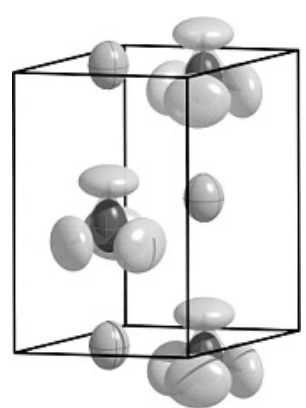

(b)
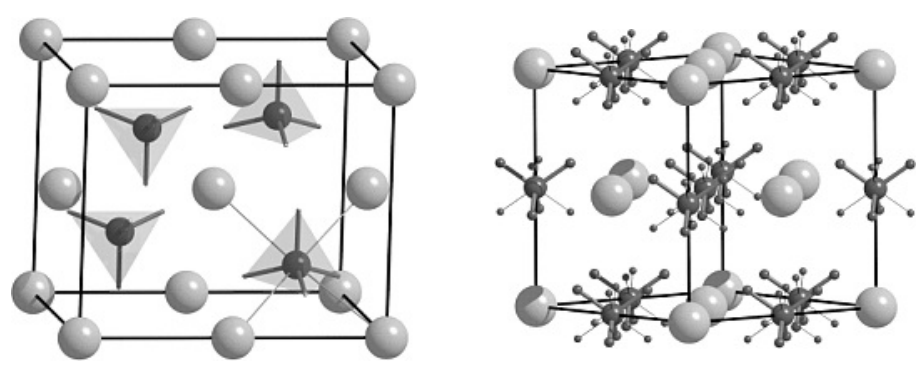

(c) (d)

Fig. 3. Crystal structure of $\mathrm{LiBH}_{4}$ phases: Pnma (a), $P 6_{3} m c$ (b), $A m a 2$ (c) and $F m \overline{3} m$ (d). Two orientations of the disordered $\mathrm{BH}_{4}$ group in the cubic phase are shown by bold and thin lines.

to the $c$-axis. These layers are corrugated in the Pnma phase, they flatten and the distance between them increases at higher temperatures (Hagemann et al., 2009). Directional interaction of the tetrahedral $\mathrm{BH}_{4}$ with the spherical metal atoms explains the relative complexity of $\mathrm{LiBH}_{4}$ structures and of the $p-T$ phase diagram as compared to $\mathrm{NaCl}$, where both the cation and the anion are spherical.

$\mathrm{NaBH}_{4}$. Under ambient conditions $\mathrm{NaBH}_{4}$ has a cubic structure, isomorphous to $\mathrm{NaCl}$, desribed in either $F m \overline{3} m$ or $F \overline{4} 3 m$ space groups. The estimated enthalpy of the transition at $\sim 190 \mathrm{~K}$ (Johnston and Hallett, 1953) is consistent with the transformation from the fully orientationally disordered high-temperature cubic phase to the ordered lowtemperature tetragonal phase. Therefore, the cubic phase should have the $F m \overline{3} m$ space group symmetry (Stockmayer and Stephenson, 1953), as later confirmed using synchrotron diffraction on a single crystal at $200 \mathrm{~K}$ (Filinchuk and Hagemann, 2008). On cooling below $\sim 190 \mathrm{~K}$ (Fischer and Züttel, 2004) or upon a compression to $\sim 6 \mathrm{GPa}$ at room temperature (Kumar and Cornelius, 2005) a phase with closely related ordered tetragonal structure appears. It was first reported in the space group $P \overline{4} 2_{1} c$ (Fischer and Züttel, 2004) but later revised in a higher symmetry $\mathrm{P}_{2} / \mathrm{nm}$ (Babanova et al., 2010). Comparing to the cubic phase, the $\mathrm{BH}_{4}$ groups in the tetragonal phase are ordered in two different orientations. As a result, the number of the

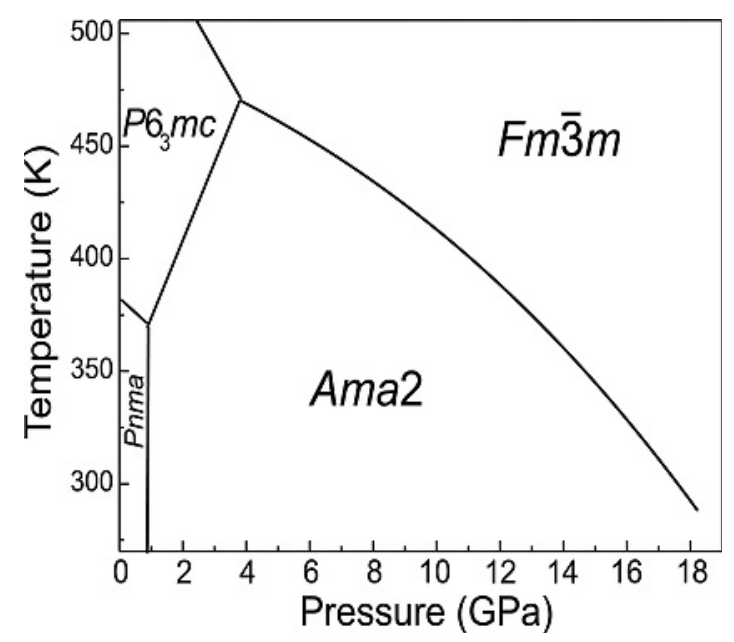

Fig. 4. $p-T$ phase diagram of $\mathrm{LiBH}_{4}$ from synchrotron powder diffraction experiments (Dmitriev et al., 2008). shortest $\mathrm{H} \ldots \mathrm{H}$ contacts in the tetragonal phase is reduced by one third comparing to the disordered cubic phase, and the network of the repulsive $\mathrm{H} \ldots \mathrm{H}$ contacts changes from isotropic three-dimensional to two-dimensional oriented in the $a b$ plane. Consequently, the $c / a$ ratio changes discontinuously from 1 to 0.964 upon the cubic-to-tetragonal transition at $\sim 186 \mathrm{~K}$ (Babanova et al., 2010) due to the contraction of the $c$-axis.

Above $\sim 9 \mathrm{GPa}$ yet another phase was detected (Kumar, Cornelius, 2005) and its structure has been solved from synchrotron powder diffraction data measured at $11.2 \mathrm{GPa}$ in $\mathrm{BaSO}_{4}$ structure type (Filinchuk et al., 2007). Both the cubic and the tetragonal phases are strongly textured in diamond anvil cells (Filinchuk et al., 2007; Chernyshov et al., 2008). For the successful solution of the tetragonal structure, it was essential to model the texture, including one parameter in the global optimization. In all three structures, $\mathrm{Na}$ atoms and $\mathrm{BH}_{4}$ groups are octahedrally coordinated.

$\mathbf{K B H}_{4}$. This substance shows a similar behaviour to $\mathrm{NaBH}_{4}$. Its cubic phase has been studied at room temperature by X-ray diffraction on single crystals (Luck, Schelter, 1999) and by neutron powder diffraction (Renaudin et al., 2004): in both cases it was described in the space group $F m \overline{3} m$. The cubic phase transforms to tetragonal at $65-70 \mathrm{~K}$ with a structure equivalent to the tetragonal $\mathrm{NaBH}_{4}$. The cation size in the cubic alkali borohydrides, $\mathrm{MBH}_{4}$ increases as $\mathrm{M}$ goes from $\mathrm{Na}$ to $\mathrm{Cs}$, thus the unit cell expands and the shortest $\mathrm{H} \ldots \mathrm{H}$ distances between the neighbouring $\mathrm{BH}_{4}$ anions increase. As a result, the weaker $\mathrm{H}$...H repulsion leads to lower temperatures of the cubicto-tetragonal transition (Renaudin et al., 2004).

$\mathbf{R b B H}_{4}$. The ambient pressure cubic phase is not observed to order at temperatures down to $10 \mathrm{~K}$ (Renaudin et al., 2004), however, it undergoes a number of pressureinduced transitions. Diffraction experiments at ambient temperature reveal three phase transitions, at 3.0, 10.4 and $18 \mathrm{GPa}$, at which the space group symmetry changes in the order $F m \overline{3} m \rightarrow P 4 / n m m \rightarrow C 222 \rightarrow I \overline{4} 2 m$ (Filinchuk et al., 2010b). The three high-pressure structure types are new in the crystal chemistry of borohydrides. $\mathrm{RbBH}_{4}$ polymorphs reveal high coordination numbers $(\mathrm{CNs})$ for cation and anion sites, increasing with pressure from 6 to 8 , via an intermediate $4+4$ coordination. Different arrangements of the tetrahedral $\mathrm{BH}_{4}$ group in the $\mathrm{Rb}$ environment define the crystal symmetries of the $\mathrm{RbBH}_{4}$ poly- 
morphs. The resulting close-packed structures confirm the highly ionic bonding scheme in $\mathrm{RbBH}_{4}$. The structural evolution in the $M \mathrm{BH}_{4}$ series is determined by the cation sizes, as it differs drastically for $M=\mathrm{Li}(\mathrm{CNs}=4,6), \mathrm{Na}$ $(\mathrm{CN}=6)$, and $\mathrm{Rb}$. The only structure common to the whole $\mathrm{MBH}_{4}$ family is the cubic $\mathrm{NaCl}$ type, which is a typical ionic crystal. Its bulk modulus linearly decreases as the ionic radius of $\mathrm{M}$ increases, indicating that the compressibility of the material is mainly determined by the repulsive $\mathrm{BH}_{4} \ldots \mathrm{BH}_{4}$ interactions (Filinchuk et al., 2010b).

LiK $\left(\mathbf{B H}_{4}\right)_{2}$. The first bi-alkali metal borohydride, LiK $\left(\mathrm{BH}_{4}\right)_{2}$, has been obtained recently by Nickels et al., 2008. $\mathrm{Li}$ and $\mathrm{K}$ atoms have four and seven $\mathrm{BH}_{4}$ neighbours, respectively. The decomposition temperature for this compound is nearly an average of those for the two components. The distortion of the $\mathrm{BH}_{4}$ anions observed in $\mathrm{LiK}\left(\mathrm{BH}_{4}\right)_{2}$ is rather related to experimental inaccuracies than to an influence of the polarizing cations suggested by Nickels et al., 2008.

\section{Borohydrides with directionality in the $M-\mathrm{BH}_{4}$ bonding}

$\mathbf{B e}\left(\mathbf{B H}_{4}\right)_{2}$. The only known phase was studied by single crystal X-ray diffraction (Marynick and Lipscomb, 1972). Its tetragonal structure contains helical polymeric chains, where the only independent $\mathrm{Be}$ cation is coordinated by two bridging borohydride anions and one terminal borohydride anion. Be atom has a trigonal-planar environment made by three $\mathrm{BH}_{4}$ groups, and the bridging $\mathrm{BH}_{4}$ group has a linear $\mathrm{Be}-\mathrm{B}-\mathrm{Be}$ geometry. Thus, the low coordination number for the $\mathrm{Be}$ atom leads to a reduced dimensionality (1D) of the polymeric structure, where coordination potential of the $\mathrm{BH}_{4}$ ligands is not fully realized.

$\mathbf{M g}\left(\mathbf{B H}_{4}\right)_{2}$. The first polymorph, $\alpha-\mathrm{Mg}\left(\mathrm{BH}_{4}\right)_{2}$, has been reported in $P 6_{1}$ space group symmetry by two independent groups (Černý et al., 2007; Her et al., 2007) using powder diffraction data. However, DFT studies suggested a possibly higher $P 6_{1} 22$ symmetry (Dai et al., 2008), which was confirmed by single-crystal diffraction at $100 \mathrm{~K}$ (Filinchuk et al., 2009b). Analysis of the published $P 6_{1}$ models shows that the location of the $\mathrm{H}$-atoms from powder data posed the main problem for the identification of the correct symmetry. The $\alpha$-phase transforms into an orthorhombic phase above $490 \mathrm{~K}$. The latter is metastable on cooling, showing anomalous cell parameter temperature dependence (Filinchuk et al., 2009b). The orthorhombic phase exhibit sharp diffraction peaks and can be described by an Immm structure with all peaks modeled, assuming an anti-site disorder, in the eight times bigger super cell with $F d d d$ symmetry (Her et al., 2007).

An intriguing aspect of the $\mathrm{Mg}\left(\mathrm{BH}_{4}\right)_{2}$ structures is their complexity. On the local level, both phases possess the same principles of structural organization. Each $\mathrm{Mg}$ atom is surrounded by four $\mathrm{BH}_{4}$ tetrahedra in a strongly deformed tetrahedral environment, while each $\mathrm{BH}_{4}$ is nearly linearly coordinated by two $\mathrm{Mg}$ cations via the opposite tetrahedral edges. $\alpha-\mathrm{Mg}\left(\mathrm{BH}_{4}\right)_{2}$ contains an unoccupied void, accounting for $6.4 \%$ of space in the structure (Filinchuk et al., 2009b). It is large enough $\left(37 \AA^{3}\right)$ to accommodate a small

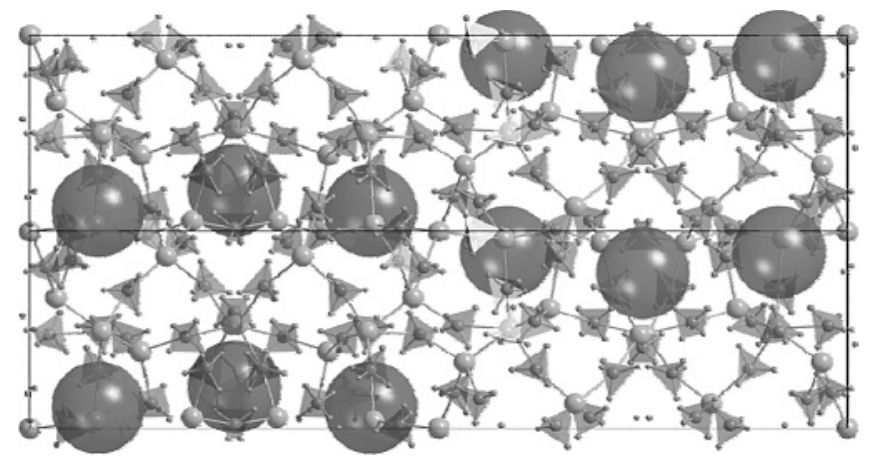

Fig. 5. Crystal structure of $\alpha-\mathrm{Mg}\left(\mathrm{BH}_{4}\right)_{2}$, where the unoccupied voids are shown as large spheres (Filinchuk et al., 2009b).

molecule, such as $\mathrm{H}_{2} \mathrm{O}$ (see Fig. 5). The high-temperature $\beta$-phase is $\sim 3 \%$ less dense and contains no unoccupied voids. Unusual crystal chemistry and the high structural complexity of $\mathrm{Mg}\left(\mathrm{BH}_{4}\right)_{2}$ is unprecedented for this class of compounds, but typical for the coordination polymers, such as MOFs, highlighting the structure-forming character of the directional $\mathrm{BH}_{4} \ldots \mathrm{M}$ interaction. ${ }^{1} \mathrm{H}$ and ${ }^{11} \mathrm{~B}$ spin-lattice relaxation NMR study of the $\mathrm{BH}_{4}$ reorientational motion support the highly anisotropic $\mathrm{BH}_{4} \ldots \mathrm{Mg}$ interaction in $\alpha-\mathrm{Mg}\left(\mathrm{BH}_{4}\right)_{2}$ (Skripov et al., 2010).

$\mathbf{C a}\left(\mathbf{B H}_{4}\right)_{2}$. Riktor et al., 2007 reported on existence of several $\mathrm{Ca}\left(\mathrm{BH}_{4}\right)_{2}$ phases. The structure of the $\alpha$-phase was first reported by Miwa et al., 2006 in the space group $F d d d$ and later revised in F2dd by Filinchuk et al., 2009c. Besides much better fit to the powder diffraction data, the noncentrosymmetric structure shows a group-subgroup relation with the symmetry of the high-temperature phase. The latter forms via a second order phase transition at $\sim 495 \mathrm{~K}$ and was described in the space group $I \overline{4} 2 d$ (Filinchuk et al., 2009c). Above $450 \mathrm{~K}$, the closely related $F 2 d d$ and $I \overline{4} 2 d$ phases kinetically transform into a completely different $\beta$-phase. Determination of its space group symmetry is ambiguous, and its structure was described in two similar models, giving the lowest DFT energies, namely in the space groups $\mathrm{P}_{2} / \mathrm{m}$ (Buchter et al., 2008) and $P \overline{4}$ (Filinchuk et al., 2009c). It is likely that the $\mathrm{BH}_{4}$ group in $\beta-\mathrm{Ca}\left(\mathrm{BH}_{4}\right)_{2}$ is intrinsically disordered, similar to the high-temperature phase of $\mathrm{LiBH}_{4}$ (Filinchuk et al., 2008a). According to the systematic absences of the diffraction peaks the true symmetry of the disordered structure might be $\mathrm{P}_{2} \mathrm{~nm}$ (Filinchuk et al., 2009c). The hightemperature phase is $4-6 \%$ denser than the $F 2 d d$ and $I \overline{4} 2 d$ phases, it is metastable on cooling, and at room temperature it slowly transforms back into the orthorhombic phase (Fichtner et al., 2008). Another phase, called $\gamma-\mathrm{Ca}\left(\mathrm{BH}_{4}\right)_{2}$, obtained by wet chemical synthesis, has an orthorhombic structure (Buchter et al., 2009). It is metastable at all temperatures and irreversibly transforms into the $\beta$-phase at $\sim 590 \mathrm{~K}$. Crystal structures of all four $\mathrm{Ca}\left(\mathrm{BH}_{4}\right)_{2}$ phases contain calcium cations virtually octahedrally coordinated by six borohydride anions, which suggest a high degree of ionic character, however, the existence of non-densely packed phases points towards directionality in the $\mathrm{Ca}-\mathrm{BH}_{4}$ bonding.

$\mathbf{M n}\left(\mathbf{B H}_{4}\right)_{2}$. The first crystal structure of a $3 d$-metal borohydride has been determined only recently for $\mathrm{Mn}\left(\mathrm{BH}_{4}\right)_{2}$ 
by Černý et al., 2009. The compound forms at ambient conditions in ball-milled mixtures of alkali metal borohydrides and $\mathrm{MnCl}_{2}$, crystallizes with the space group symmetry $P 3_{1} 12$ and is stable from 90 up to $450 \mathrm{~K}$, where the compound melts. The structure of $\mathrm{Mn}\left(\mathrm{BH}_{4}\right)_{2}$ shows a close similarity to $\alpha-\mathrm{Mg}\left(\mathrm{BH}_{4}\right)_{2}$, both with respect to the local atoms environment and in terms of the structural organization. Moreover, $\mathrm{Mn}\left(\mathrm{BH}_{4}\right)_{2}$ is not densely packed and contains isolated voids with estimated volume of $21 \AA^{3}$ each, which occupy in total $6 \%$ of the space. Furthermore, mixed $(\mathrm{Mg}, \mathrm{Mn})\left(\mathrm{BH}_{4}\right)_{2}$ was observed by Černý et al., 2010d.

$\mathbf{A l}\left(\mathbf{B H}_{4}\right)_{3}$. At ambient conditions, this substance is a liquid. However, two crystalline phases are known at low temperatures, with a transition temperature in the range 180 to $195 \mathrm{~K}$. Their structures have been studied by single-crystal X-ray diffraction (Aldridge et al., 1997). Each phase is made up of discrete $\mathrm{Al}\left(\mathrm{BH}_{4}\right)_{3}$ units, where $\mathrm{Al}$ has a trigonal-planar environment of the $\mathrm{BH}_{4}$ groups coordinated via the tetrahedral edges. Locally, the $\mathrm{Al}\left(\mathrm{BH}_{4}\right)_{3}$ structures resemble the one for $\mathrm{Be}\left(\mathrm{BH}_{4}\right)_{2}$.

$\mathbf{Y}\left(\mathbf{B H}_{4}\right)_{3}$. Two polymorphs, a low and high temperature phase denoted $\alpha$ - and $\beta-\mathrm{Y}\left(\mathrm{BH}_{4}\right)_{3}$, respectively, are found for this compound,. Ball milling $\mathrm{LiBH}_{4}$ and $\mathrm{YCl}_{3}$ yields $\alpha-\mathrm{Y}\left(\mathrm{BH}_{4}\right)_{3}$ and in some cases small amounts of $\beta$ $\mathrm{Y}\left(\mathrm{BH}_{4}\right)_{3}$. Transformation from $\alpha$ - to $\beta-\mathrm{Y}\left(\mathrm{BH}_{4}\right)_{3}$ is obtained by annealing in a narrow temperature interval of $450-$ $475 \mathrm{~K}$, as the decomposition starts above. The high-temperature phase is stable on cooling. The two phases have closely related cubic structures, the major difference is in the ordering schemes for the $\mathrm{BH}_{4}$ anions and the deformation of the octahedral environment for the $\mathrm{Y}$ atom: in the low-temperature $P a \overline{3}$ phase it is distorted (Sato et al., 2008), while in the high-temperature phase it is undistorted. Furthermore, the high-temperature phase is $4.6 \%$ less dense than the low temperature one and contains relatively large unoccupied voids of $39 \AA^{3}$, accounting for almost a quarter of the volume.

The metal atom substructure in the high-temperature phase, detected by synchrotron X-ray powder diffraction, has the regular $\mathrm{ReO}_{3}$ type (Ravnsbæk et al., 2010c). An independent study by neutron powder diffraction (Frommen et al., 2010) revealed a $F m \overline{3} c$ superstructure with an ordered arrangement of the $\mathrm{BH}_{4}$ groups, where half of these are flipped to minimize $\mathrm{H}-\mathrm{H}$ repulsion on the cost of a less densely packed structure (Fig. 6). This study shows that X-rays alone may see only half the truth: The only superstructure reflection is of very low intensity and is difficult to detect in a typical measured X-ray pattern. However this reflection becomes the strongest peak in a neutron pattern. In a DFT study by Lee, Shim and Cho, 2010, the high calculated energy barrier for the $\mathrm{BH}_{4}$ ordering was found to partly account for the slow phase transition observed in $\mathrm{Y}\left(\mathrm{BH}_{4}\right)_{3}$, in contrast with the facile $\mathrm{BH}_{4}$ flipping in $\mathrm{NaBH}_{4}$.

$\mathbf{M S c}\left(\mathrm{BH}_{4}\right)_{\mathbf{4}}(\boldsymbol{M}=\mathbf{L i}, \mathbf{N a}, \mathbf{K})$. These compounds can be described as complexes containing a discrete tetrahedral $\left[\mathrm{Sc}\left(\mathrm{BH}_{4}\right)_{4}\right]^{-}$anion. In all cases $\mathrm{Sc}$ atom coordinates the $\mathrm{BH}_{4}$ groups via the faces, yielding a 12-fold coordination by $\mathrm{H}$ atoms. In $\mathrm{LiSc}\left(\mathrm{BH}_{4}\right)_{4}$ the $\mathrm{Li}$ ions are disordered along the $z$ axis of the tetragonal cell, thus the coordination of the $\mathrm{Li}$ atom is not clearly defined (Hagemann

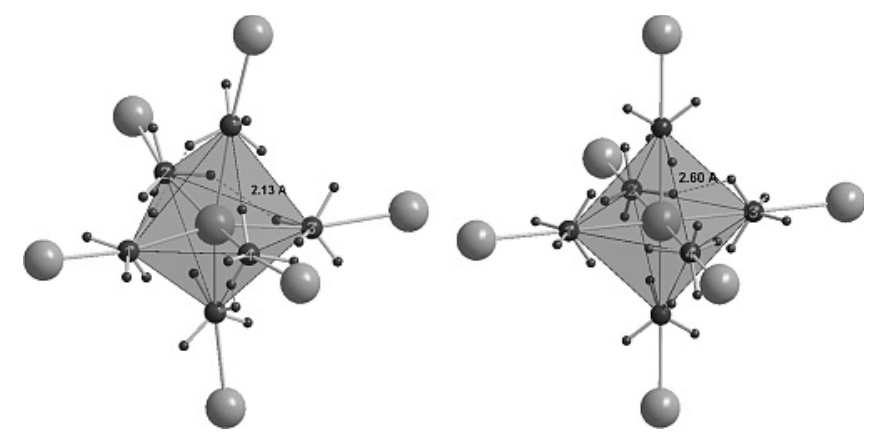

Fig. 6. Yttrium coordination in the low-temperature (left) and hightemperature (right) phases of $\mathrm{Y}\left(\mathrm{BH}_{4}\right)_{3}$ (Ravnsbæk et al., 2010c). Two $\mathrm{BH}_{4}$ groups in equatorial plane (marked 3 and 4) and the upper appical group are flipped when LT-phase transforms to HT-phase creating less packed structure but with no short $\mathrm{H}-\mathrm{H}$ contacts.

et al., 2008). The structure of $\mathrm{NaSc}\left(\mathrm{BH}_{4}\right)_{4}$ (Černý et al., 2010a) consists of the similar isolated $\left[\mathrm{Sc}\left(\mathrm{BH}_{4}\right)_{4}\right]^{-}$anions located inside slightly deformed trigonal prisms of $\mathrm{Na}$ atoms. The packing of $\mathrm{Na}^{+}$cations and $\left[\mathrm{Sc}\left(\mathrm{BH}_{4}\right)_{4}\right]^{-}$anions in $\mathrm{NaSc}\left(\mathrm{BH}_{4}\right)_{4}$ is a deformation variant of the hexagonal NiAs structure type. The structure of $\mathrm{KSc}\left(\mathrm{BH}_{4}\right)_{4}$ (Črný et al., 2010b) is of the $\mathrm{BaSO}_{4}$ type where the $\mathrm{BH}_{4}$ tetrahedra are on the positions of oxygen. Regarding the packing of $\mathrm{K}^{+}$cations and $\left[\mathrm{Sc}\left(\mathrm{BH}_{4}\right)_{4}\right]^{-}$anions in $\mathrm{KSc}\left(\mathrm{BH}_{4}\right)_{4}$, the structure can be seen as a distorted variant of the orthorhombic Np metal structure type. The structural organization in this series suggests a close packing of $\mathrm{M}^{+}$cations and $\left[\mathrm{Sc}\left(\mathrm{BH}_{4}\right)_{4}\right]^{-}$anions.

$\boldsymbol{M Z n}_{\mathbf{2}}\left(\mathbf{B H}_{4}\right)_{\mathbf{5}}(\boldsymbol{M}=\mathbf{L i}, \mathbf{N a}) \cdot \mathrm{LiZn}_{2}\left(\mathrm{BH}_{4}\right)_{5}$ represent a novel type of structure which has no distinct analogues among other known inorganic compounds (Ravnsbæk et al., 2009). The structure of $\mathrm{NaZn}_{2}\left(\mathrm{BH}_{4}\right)_{5}$ is a monoclinical distorted derivative of the orthorhombic Li-containing analogue. Two independent $\mathrm{Zn}$ atoms in $M \mathrm{Zn}_{2}\left(\mathrm{BH}_{4}\right)_{5}$ have a trigonal-planar coordination by three $\mathrm{BH}_{4}$ groups, similar to the $\mathrm{Be}$ atoms in $\mathrm{Be}\left(\mathrm{BH}_{4}\right)_{2}$ (Marynick, Lipscomb, 1972). The $\mathrm{BH}_{4}$ groups are almost linearly coordinated by two metal atoms (the angles vary from 164.5 to $179.6^{\circ}$ ) via the two opposite edges, bridging either two $\mathrm{Zn}$

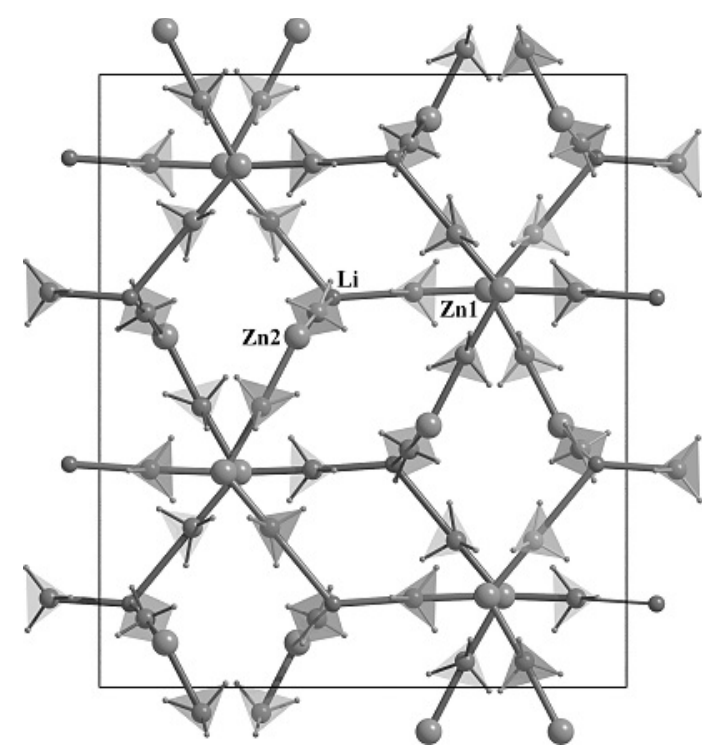

Fig. 7. The doubly interpenetrated three-dimensional framework in $\mathrm{LiZn}_{2}\left(\mathrm{BH}_{4}\right)_{5}$ (Ravnsbæk et al., 2009), highlighted in blue and red. 
atoms or one $\mathrm{Zn}$ and one $\mathrm{M}$ atom. It is remarkable that $M \mathrm{Zn}_{2}\left(\mathrm{BH}_{4}\right)_{5}$ consists of two identical doubly-interpenetrated three-dimensional (3D) frameworks (Fig. 7). This type of structural topology, which suggests directionality of the metal- $\mathrm{BH}_{4}$ interaction, is common for the coordination polymers involving organic ligands but observed for the first time in metal hydrides. Considering only the strongly associated $\mathrm{Zn}$ atoms and $\mathrm{BH}_{4}$ units, the $M \mathrm{Zn}_{2}\left(\mathrm{BH}_{4}\right)_{5}$ compounds contain isolated $\left[\mathrm{Zn}_{2}\left(\mathrm{BH}_{4}\right)_{5}\right]^{-}$anions, counter-balanced by cations $\mathrm{M}^{+}$.

$\operatorname{NaZn}\left(\mathbf{B H}_{4}\right)_{3}$. This phase shows a new type of structure, containing a 3D framework of the metal atoms and the $\mathrm{BH}_{4}$ groups. Two independent studies by synchrotron X-ray powder diffraction (Ravnsbæk et al., 2009; Černý et al., 2010b) showed that $\mathrm{Zn}$ atoms in $\mathrm{NaZn}\left(\mathrm{BH}_{4}\right)_{3}$ have an intermediate coordination between a distorted tetrahedral and a flat-trigonal, while the DFT optimization of the experimental structures clearly prefers and IR spectra agree with the latter (Černý et al., 2010b). Hence the compound may be rationalized as containing isolated $\left[\mathrm{Zn}\left(\mathrm{BH}_{4}\right)_{3}\right]^{-}$anions counter-balanced by cations $\mathrm{M}^{+}$. Similar to $\mathrm{NaZn}_{2}\left(\mathrm{BH}_{4}\right)_{5}$, the $\mathrm{Na}$ atom has a saddle-like coordination by the $\mathrm{BH}_{4}$ groups.

$\mathbf{L i}_{4} \mathbf{A l}_{3}\left(\mathbf{B H}_{4}\right)_{13}$. Its $P \overline{4} 3 n$ structure was determined from synchrotron X-ray powder diffraction data supported by DFT calculations (Lindemann et al., 2010). The unexpected composition can be rationalized on the basis of a complex cation $\left[\left(\mathrm{BH}_{4}\right) \mathrm{Li}_{4}\right]^{3+}$ and a complex anion $\left[\mathrm{Al}\left(\mathrm{BH}_{4}\right)_{4}\right]^{-}$. The refinements from synchrotron powder diffraction of different samples revealed the presence of limited amounts of chloride ions replacing the borohydride on one site.

\section{Anion substituted derivatives}

$\mathbf{K Z n}\left(\mathrm{BH}_{4}\right) \mathrm{Cl}_{2}$ and $\mathrm{NaY}\left(\mathrm{BH}_{4}\right)_{2} \mathrm{Cl}_{2}$. The first compound (Ravnsbæk et al., 2010a) contains a heteroleptic complex anion $\left[\mathrm{Zn}\left(\mathrm{BH}_{4}\right) \mathrm{Cl}_{2}\right]^{-}$, where $\mathrm{Zn}$ has a nearly flat trigonal environment. $\mathrm{K}$ atom, having 8 neighbouring anions, acts like a counter-ion. The second compound is polymeric (Ravnsbæk et al., 2010b). Its pseudo-orthorhombic crystal structure is built of edge- and corner-sharing octahedral coordination polyhedra of yttrium coordinated to $4 \mathrm{Cl}$ and $2 \mathrm{BH}_{4}$ and sodium coordinated to $2 \mathrm{Cl}$ and $4 \mathrm{BH}_{4}$. Combination of the second anion, such as a halide or an amide (Filinchuk et al., 2006), extends the structural diversity of metal borohydrides. Combining different ligands in modified metal borohydrides is one of the ways to adjust their stability with respect to hydrogen desorption.

$\mathbf{L i}\left(\mathbf{B H}_{4}\right)_{1-x} \mathbf{C l}_{x} \cdot \mathrm{LiBH}_{4}-\mathrm{LiCl}$ is the first system where a gradual replacement of $\mathrm{BH}_{4}$ has been found (Mosegaard et al., 2008), showing a partial replacement of the borohydride anions by chloride anions at elevated temperatures $(>389 \mathrm{~K})$. The size of anions change according to the sequence $\mathrm{I}^{-}>\mathrm{BH}_{4}^{-}>\mathrm{Br}^{-}>\mathrm{Cl}^{-}$(Filinchuk and Hagemann, 2008), giving an efficient tool to tune the unit cell volume and an internal lattice pressure in borohydrides. Even the small chloride anion stabilize the hexagonal phase at significantly lower temperatures, the latter depending on the degree of the anion substitution (Arnbjerg et al., 2009). Heating a $\mathrm{LiBH}_{4}-\mathrm{LiCl}$ mixture produces highly chloride-substituted hexagonal lithium borohydride,
$\operatorname{Li}\left(\mathrm{BH}_{4}\right)_{1-x} \mathrm{Cl}_{x}$, with $x \sim 0.42$. At higher temperatures the solubility is higher, and the process of the $\mathrm{LiCl}$ entrance into $\mathrm{LiBH}_{4}$ is reversible on heating/cooling (Arnbjerg et al., 2009). The orthorhombic low-temperature $\mathrm{LiBH}_{4}$ phase shows a lower solubility of $\mathrm{LiCl}$ than the hexagonal one. Notice, there is no indications of any dissolution of $\mathrm{LiBH}_{4}$ in $\mathrm{LiCl}$.

$\mathbf{C a}\left(\mathbf{B H}_{4}\right)_{2}{ }_{-x} \mathbf{I}_{x}$. A partial substitution of the $\mathrm{BH}_{4}$ group by halide anions opens the way to modify metal borohydrides and influence their structural stability. During ball milling, calcium borohydride readily dissolves in the trigonal calcium iodide structure, forming a solid solution $\mathrm{Ca}\left(\mathrm{BH}_{4}\right)_{2-x} \mathrm{I}_{x}$ with an anisotropically contracted trigonal unit cell. It transforms at $\sim 450 \mathrm{~K}$ to an orthorhombic phase of the same composition with a $\mathrm{CaCl}_{2}$-type structure (distorted $\beta-\mathrm{Ca}\left(\mathrm{BH}_{4}\right)_{2}$ ). Further heating leads to a transition to a tetragonal phase having a new structure type. It was observed for the series of I-substituted $\mathrm{Ca}\left(\mathrm{BH}_{4}\right)_{2}$ (Rude et al., 2010) that the smaller anion tends to dissolve in the compound containing the larger anion. Furthermore, it has been shown that $10 \% \mathrm{CaCl}_{2}$ can dissolve into the lattice of $\beta$ - $\mathrm{Ca}\left(\mathrm{BH}_{4}\right)_{2}$ whereas no dissolution is observed in the system of $\beta-\mathrm{Ca}\left(\mathrm{BH}_{4}\right)_{2}-\mathrm{CaF}_{2}$ (Lee et al., 2010).

\section{Reactive hydride composites}

A significant challenge for the possible future utilisation of metal borohydrides for hydrogen storage materials is discovering new reversible systems that function under technically viable conditions. Secondly, stabilisation of boron in the solid dehydrogenated phase is also important, i.e. suppression of release of borane gasses. Recently, Barkhordarian, Klassen and Bormann, 2005 and Vajo, Skeith and Mertens, 2005 discovered a very promising class of reversible hydrogen storage systems and demonstrated that different light metal/complex metal hydrides, so-called reactive hydride composites $(\mathrm{RCH})$, may react during release of hydrogen, see Eqs. (6) and (7).

$$
\begin{aligned}
& 2 \mathrm{LiBH}_{4}+\mathrm{MgH}_{2} \leftrightarrow 2 \mathrm{LiH}+\mathrm{MgB}_{2}+4 \mathrm{H}_{2}, \\
& \mathrm{Ca}\left(\mathrm{BH}_{4}\right)_{2}+\mathrm{MgH}_{2} \leftrightarrow \mathrm{CaH}_{2}+\mathrm{MgB}_{2}+4 \mathrm{H}_{2} .
\end{aligned}
$$

This may provide a more useful reaction enthalpy and reversibility at more moderate conditions as compared to the individual hydrides.

However, the desorption temperatures of the investigated systems are still higher than predicted by estimations based on thermodynamic considerations and therefore limited by kinetic constraints. Hence, studies by different means to solve this problem are of vital importance and in situ X-ray powder diffraction conducted at variable temperature or pressure has proven to be a powerful tool, and a variety of other different RHC systems have also been studied, e.g. $\mathrm{LiBH}_{4}-\mathrm{Al}$ (Jin et al., 2008, Friedrich et al., 2009), $\mathrm{LiBH}_{4}-\mathrm{LiAlH}_{4}$ (Mao et al., 2007), $\mathrm{LiBH}_{4}-\mathrm{NaAlH}_{4}$ (Shi et al., 2008; Ravnsbæk and Jensen, 2010e) and $\mathrm{LiBH}_{4}-\mathrm{Mg}\left(\mathrm{BH}_{4}\right)_{2}$ (Fang et al., 2010). Furthermore, some mixed systems may form eutectic melts have been studied in mixtures of metal borohydrides, e.g. $\mathrm{LiBH}_{4}-\mathrm{Ca}\left(\mathrm{BH}_{4}\right)_{2}$ (Lee et al., 2009) and $\mathrm{LiBH}_{4}-\mathrm{Mg}\left(\mathrm{BH}_{4}\right)_{2}$ (Hagemann et al., 2010b). 
Studies have also shown that the drawbacks of poor kinetics may be overcome by suitable choice of catalysts (Bösenberg et al., 2010a, b) or by nanoconfinement, i.e. $\mathrm{LiBH}_{4}$ and $\mathrm{MgH}_{2}$ are infiltrated in a nanoporous carbon aerogel scaffold with pore size $D_{\max }=21$. The hydrogen desorption kinetics is significantly improved compared to bulk conditions, and the nanoconfined system has a high degree of reversibility and stability and possibly also improved thermodynamic properties. The reactions taking place in the scaffold and the actual incorporation of the materials into the nano pores have been studied in great detail by in situ X-ray powder diffraction. This new scheme of nanoconfined chemistry may have a wide range of interesting applications in the future, for example, within the merging area of chemical storage of renewable energy (Nielsen et al., 2010a).

\section{Conclusion}

Hydrogen is recognized as a possible renewable energy carrier, however, its utilization is mainly hampered by insufficient hydrogen storage capabilities. Therefore, there is an urgent need for development of novel hydrogen storage materials. We have reviewed the recent development within an interesting class of light element boron based materials, which have gained a significant number of new family members during the past few years. Several of the bimetallic borohydrides have high hydrogen contents and some also low decomposition temperatures. Decomposition temperatures in the range $100-200{ }^{\circ} \mathrm{C}$ may be associated with reduction of the metal coordinated to borohydride and release of diborane, e.g. zinc based materials. Others release hydrogen in the temperature range $200-300{ }^{\circ} \mathrm{C}$ and form metal borides. This is an indication that reversible hydrogen storage may be possible. Furthermore, the physical properties of borohydrides may be tailored by anion substitution, which illustrates significant diversity within the structural, physical and chemical properties. This new class of $\mathrm{BH}_{4}^{-}$based materials possess a fascinating structural chemistry, exhibiting bonding ranging from ionic to more covalent with some degree of directionality in the $M-\mathrm{BH}_{4}$ interaction. Metal borohydrides are often found as fine powders in synthesis products containing several compounds and the structural analysis is extremely challenging. We argue in this review, that in situ time and temperature resolved powder X-ray diffraction data is the most important analysis technique capable of providing data for structural analysis, and giving detailed insight into the structural chemistry, and chemical reactions taking place during synthesis and decomposition. This demonstrates that powder diffraction is likely our most valuable and versatile tool in order to discover and characterise novel materials, which can form the basis for new, sustainable and carbon free energy technologies.

\section{References}

Aldridge, S.; Blake, A. J.; Downs, A. J.; Gould, R. O.; Parsons, S.; Pulham, C. R.: Some tetrahydroborate derivatives of aluminium: crystal structures of dimethylaluminium tetrahydroborate and the $\alpha$ and $\beta$ phases of aluminium tris(tetrahydroborate) at low temperature. J. Chem. Soc., Dalton Trans. (1997) 1007-1012.
Andreasen, A.; Sørensen, M. B.; Burkarl, R.; Møller, B.; Molenbroek, A. M.; Pedersen, A. S.; Andreasen, J. W.; Nielsen, M. M.; Jensen, T. R.: Interaction of hydrogen with an $\mathrm{Mg}-\mathrm{Al}$ alloy. J. Alloys Compd. 404-406 (2005) 323-326.

Andreasen, A.; Sørensen, M. B.; Burkarl, R.; Møller, B.; Molenbroek, A. M.; Pedersen, A. S.; Vegge, T.; Jensen, T. R.: Dehydrogenation kinetics of air-exposed $\mathrm{MgH}_{2} / \mathrm{Mg}_{2} \mathrm{Cu}$ and $\mathrm{MgH}_{2} / \mathrm{MgCu}_{2}$ studied with in situ X-ray powder diffraction. Appl. Phys. A 82 (2006) 515- 521 .

Arnbjerg, L. M.; Ravnsbæk, D.; Filinchuk, Y.; Vang, R. T.; Cerenius, Y.; Besenbacher, F.; Jørgensen, J.-E.; Jacobsen, H. J.; Jensen, T. R.: Structure and dynamics for $\mathrm{LiBH}_{4}-\mathrm{LiCl}$ solid solutions. Chem. Mater. 21 (2009) 5772-5782.

Babanova, O.; Soloninin, A.; Stepanov, A.; Skripov, A.; Filinchuk, Y.: Structural and dynamical properties of $\mathrm{NaBH}_{4}$ and $\mathrm{KBH}_{4}$ : NMR and synchrotron X-ray diffraction studies. J. Phys. Chem. C. 114 (2010) 3712-3718.

Balema, V. P.; Wiench, J. W.; Pruski, M.; Pecharsky, V. K.; Mechanically induced solid-state generation of phosphorus ylides and the solvent free Wittig reaction. J. Am. Chem. Soc. 124 (2002) 6244-6245.

Barkhordarian, G.; Klassen, T.; Bormann, R.; German patent pending 102004061 286.2, int. patent pending PCT/EP 2005/003494.136

Bogdanović, B.; Schwickardi, M.; Ti-doped alkali metal aluminium hydrides as potential novel reversible hydrogen storage materials. J. Alloys Compd. 253-254 (1997) 1-9.

Bösenberg, U.; Kim, J. W.; Gosslar, D.; Eigen, N.; Jensen, T. R.; Bellosta von Colbe, J. M.; Zhou, Y.; Dahms, M.; Kim, D. H.; Günther, R.; Cho, Y. W.; Oh, K. H.; Klassen, T.; Bormann, R.; Dornheim, M.: Role of additives in $\mathrm{LiBH}_{4}-\mathrm{MgH}_{2}$ reactive hydride composites for sorption kinetics. Acta Mater. 58 (2010) $3381-3389$.

Bösenberg, U.; Ravnsbæk, D. B.; Hagemann, H.; D’Anna, V.; Minella, C. B.; Pistidda, C.; van Beek, W.; Safonova, O.; Jensen, T. R.; Bormann, R.; Dornheim, M.: Reaction pathway of the desorption reaction in reactive hydride composites in dependency of pressure and temperature. J. Phys. Chem. C 114 (2010) 15212-15217.

Buchter, F.; Łodziana, Z.; Remhof, A.; Friedrichs, O.; Borgschulte, A.; Mauron, Ph.; Züttel, A.; Sheptyakov, D.; Barkhordarian, G.; Bormann, R.; Chłopek, K.; Fichtner, M.; Sørby, M.; Riktor, M.; Hauback, B.; Orimo, S.: Structure of $\mathrm{Ca}\left(\mathrm{BD}_{4}\right)_{2} \beta$-phase from combined neutron and synchrotron X-ray powder diffraction data and density functional calculations. J. Phys. Chem. B. 112 (2008) 8042-8048.

Buchter, F.; Łodziana, Z.; Remhof, A.; Friedrichs, O.; Borgschulte, A.; Mauron, Ph.; Züttel, A.; Sheptyakov, D.; Palatinus, L.; Chłopek, K.; Fichtner, M.; Barkhordarian, G.; Bormann, R.; Hauback, B. C.: Structure of the orthorhombic $\gamma$-phase and phase transitions of $\mathrm{Ca}\left(\mathrm{BD}_{4}\right)_{2}$. J. Phys. Chem. C. 113 (2009) 1722317230.

Černý, R.; Favre-Nicolin, V.: Direct space methods of structure determination from powder diffraction: principles, guidelines and perspectives. Z. Kristallogr. 222 (2007) 105-113.

Černý, R.; Filinchuk, Y.; Hagemann, H.; Yvon, K.: Magnesium borohydride: synthesis and crystal structure. Angew. Chem. Int. Ed. 46 (2007) 5765-5767.

Černý, R.: Solving crystal structures of metal and chemical hydrides. Z. Kristallogr. 223 (2008) 607-616.

Černý, R.; Penin, N.; Hagemann, H.; Filinchuk, Y.: The first crystallographic and spectroscopic characterization of a 3d-metal borohydride: $\mathrm{Mn}\left(\mathrm{BH}_{4}\right)_{2}$. J. Phys. Chem. C. 113 (2009) 9003-9007.

Černý, R.; Severa, G.; Ravnsbæk, D. B.; Filinchuk, Y.; D’Anna, V.; Hagemann, H.; Haase, D.; Jensen, C. M.; Jensen, T. R.: $\mathrm{NaSc}\left(\mathrm{BH}_{4}\right)_{4}$ : A novel scandium-based borohydride. J. Phys. Chem. C. 114 (2010a) 1357-1364.

Černý, R.; Ravnsbæk, D. B.; Severa, G.; Filinchuk, Y.; D’Anna, V.; Hagemann, H.; Haase, D.; Jensen, C.M.; Jensen, T.R.: Structure and characterization of $\mathrm{KSc}\left(\mathrm{BH}_{4}\right)_{4}$. J. Phys. Chem. C (2010b) DOI: $10.1021 /$ jp106280v.

Černý, R.; Kim, K.Ch.; Penin, N.; D’Anna, V.; Hagemann, H.; Sholl, D.S.: $A \mathrm{Zn}_{2}\left(\mathrm{BH}_{4}\right)_{5}(A=\mathrm{Li}, \mathrm{Na})$ and $\mathrm{NaZn}\left(\mathrm{BH}_{4}\right)_{3}$ : structural studies J. Phys. Chem. C 114 (2010c) 19127-19133.

Černý, R.; Penin, N.; d'Anna, V.; Ruziska, J.; $\operatorname{Mg}_{x} \mathrm{Mn}\left({ }_{1-x}\right)\left(\mathrm{BH}_{4}\right)_{2}$ $(x=0-0.8)$ first cationic solid solution in a bimettalic borohydride. J. Phys. Chem. C (2009d) in preparation. 
Chernyshov, D.; Bosak, A.; Dmitriev, V.; Filinchuk, Y.; Hagemann, H.: Low lying phonons in $\mathrm{NaBH}_{4}$ studied by inelastic scattering of synchrotron radiation. Phys. Rev. B. 78 (2008) 172104.

Clausen, B.S.; Steffensen, G.; Fabius, B.; Villadsen, J.; Feidenhans'l, R.: In situ cell for combined XRD and on-line catalysis tests: Studies of $\mathrm{Cu}$-based water gas shift and methanol catalysts. Topsøe, H. J. Catal. 132 (1991) 524-535.

Coelho, A.A.: TOPAS-Academic. (2004)

http://members.optusnet.com.au/ alancoelho

Remark: Commercial version containing more comfortable GUI may be obtained from Bruker AXS.

Chupas, P. J.; Chapman, K. W.; Kurtz, C.; Hanson, J. C.; Lee, P.L.; Grey, C. P. J.: A versatile sample-environment cell for non-ambient X-ray scattering experiments. Appl. Cryst. 41 (2008) 822-824.

Dai, B.; Sholl, D. S.; Johnson, J. K.: First-principles study of experimental and hypothetical $\operatorname{Mg}\left(\mathrm{BH}_{4}\right)_{2}$ crystal structures. J. Phys. Chem. C. 112 (2008) 4391-4395.

David, W.I.F. ; Shankland, K.: Structure determination from powder diffraction data. Acta Cryst. A64 (2008) 52-64.

Dmitriev, V.; Filinchuk, Y.; Chernyshov, D.; Talyzin, A.; Dzwilewski, A.; Andersson, O.; Sundqvist, B.; Kurnosov, A.: Pressure-temperature phase diagram of $\mathrm{LiBH}_{4}$ : synchrotron X-ray diffraction experiments and theoretical analysis. Phys. Rev. B. 77 (2008) 174112.

Dornheim, M.; Doppiu, S.; Barkhordarian, G.; Boesenberg, U.; Klassen, T.; Gutfleisch, O.; Bormann, R.: Hydrogen storage in magnesium-based hydrides and hydride composites. Scr. Mater. 56 (2007) 841-846.

Eberle, U.; Felserhoff, M.; Schüth, F.: Chemical and physical solutions for hydrogen storage. Angew. Chem. Int. Ed. 48 (2009) $6608-6630$.

Efron, B.; Tibshirani, R.: Bootstrap methods for standard errors, confidence intervals, and other measures of statistical accuracy. Stat. Science 1 (1986) 54-77.

Fang, Z.-Z.; Kang, X.-D.; Wang, P.; Li, H.-W.; Orimo, S.-I.: Unexpected dehydrogenation behavior of $\mathrm{LiBH}_{4} / \mathrm{Mg}\left(\mathrm{BH}_{4}\right)_{2}$ mixture associated with the in situ formation of dual-cation borohydride. J. Alloys Comp. 491 (2010) L1-L4.

Favre-Nicolin, V.; Černý, R.: FOX, "Free objects for crystallography": a modular approach to ab initio structure determination from powder diffraction. J. Appl. Crystallography 35 (2002) 734743. See also http://objcryst.sourceforge.net/Fox.

Fichtner, M.; Chłopek, K.; Longhini, M.; Hagemann H.: Vibrational spectra of $\mathrm{Ca}\left(\mathrm{BH}_{4}\right)_{2}$. J. Phys. Chem. C. 112 (2008) 1157511579 .

Filinchuk, Y. E.; Yvon, K.; Meisner, G. P.; Pinkerton, F. E.; Balogh, M. P.: On the composition and crystal structure of the new quaternary hydride phase $\mathrm{Li}_{4} \mathrm{BN}_{3} \mathrm{H}_{10}$. Inorg. Chem. 45 (2006) $1433-$ 1435.

Filinchuk, Y.; Talyzin, A.; Chernyshov, D.; Dmitriev, V.: High-pressure phase of $\mathrm{NaBH}_{4}$ : crystal structure from synchrotron powder diffraction data. Phys. Rev. B. 76 (2007) 092104

Filinchuk, Y.; Hagemann, H.: Structure and properties of $\mathrm{NaBH}_{4} \cdot 2 \mathrm{H}_{2} \mathrm{O}$ and $\mathrm{NaBH}_{4}$. Eur. J. Inorg. Chem. (2008) 31273133.

Filinchuk, Y.; Chernyshov, D.; Černý, R.: The lightest borohydride probed by synchrotron diffraction: experiment calls for a new theoretical revision. J. Phys. Chem. C. 112 (2008a) 10579-10584.

Filinchuk, Y.; Chernyshov, D.; Dmitriev, V.: Light metal borohydrides: crystal structures and beyond. Z. Kristallogr. 223 (2008b) 649-659.

Filinchuk, Y.; Chernyshov, D.; Nevidomskyy, A.; Dmitriev, V.: Highpressure polymorphism as a step towards destabilization of $\mathrm{LiBH}_{4}$. Angew. Chem. Int. Ed. 47 (2008c) 529-532.

Filinchuk, Y.; Nevidomskyy, A. H.; Chernyshov, D.; Dmitriev V.: High-pressure phase and transition phenomena in ammonia borane $\mathrm{NH}_{3} \mathrm{BH}_{3}$ from X-ray diffraction, Landau theory, and ab initio calculations. Phys. Rev. B. 79 (2009a) 214111.

Filinchuk, Y.; Černý, R.; Hagemann, H.: Insight into $\mathrm{Mg}\left(\mathrm{BH}_{4}\right)_{2}$ with synchrotron X-ray diffraction: structure revision, crystal chemistry, and anomalous thermal expansion. Chem. Mater. 21 (2009b) 925-933.

Filinchuk, Y.; Rönnebro, E.; Chandra, D.: Crystal structures and phase transformations in $\mathrm{Ca}\left(\mathrm{BH}_{4}\right)_{2}$. Acta Mater. 57 (2009c) 732-738.
Filinchuk, Y.: Light metal hydrides under non-ambient conditions: probing chemistry by diffraction? In "High-pressure crystallography", ed. E. Boldyreva and P. Dera, NATO Science for Peace and Security Series B (2010) 281-291.

Filinchuk, Y.; Chernyshov, D.; Dmitriev, V.: Crystal chemistry of light metal borohydrides. In "Boron hydrides, high potential hydrogen storage materials", ed. U.B. Demirci and P. Miele, Nova Publishers (2010a); arXiv: abs/1003.5378.

Filinchuk, Y.; Talyzin, A. V.; Hagemann, H.; Dmitriev, V.; Chernyshov, D.; Sundqvist, B.: Cation size and anion anisotropy in structural chemistry of metal borohydrides. The peculiar pressure evolution of $\mathrm{RbBH}_{4}$. Inorg. Chem. 49 (2010b) 5285-5292.

Fischer, P.; Züttel, A.: Order-disorder phase transition in $\mathrm{NaBD}_{4}$. Mater. Sci. Forum. 443-444 (2004) 287-290.

Friedrichs, O.; Kim, J. W.; Remhof, A.; Buchter, F.; Borgschulte, A.; Wallacher, D.; Cho, Y. W.; Fichtner, M.; Oh, K. H.; Züttel, A.: The effect of $\mathrm{Al}$ on the hydrogen sorption mechanism of $\mathrm{LiBH}_{4}$. Phys. Chem. Chem. Phys. 11 (2009) 1515-1520.

Frommen, C.; Aliouane, N.; Daledda, S.; Fonneløp, J. E.; Grove, H.; Lieutenant, K.; Llamas-Jansa, I.; Sartori, S.; Sørby, M. H.; Hauback, B. C.: Crystal structure, polymorphism, and thermal properties of yttrium borohydride $\mathrm{Y}\left(\mathrm{BH}_{4}\right)_{3}$. J. Alloys Compd. 496 (2010) 710-716.

Gray, E. Mac.; Cookson, D. J.; Blach, T. P.: X-ray diffraction cell for studying solid-gas reactions under gas pressures to 100 bar. J. Appl. Crystallogr. 39 (2007) 850-855.

Grochala, W.; Edwards, P. P.: Thermal decomposition of the non-interstitial hydrides for the storage and production of hydrogen. Chem. Rev. 104 (2004) 1283-1315.

Hagemann, H.; Longhini, M.; Kaminski, J. W.; Wesolowski, T. A.; Černý, R.; Penin, N.; Sorby, M. H.; Hauback, B. C.; Severa, G.; Jensen, C. M.: $\operatorname{LiSc}\left(\mathrm{BH}_{4}\right)_{4}$, a new complex salt with discrete $\mathrm{Sc}\left(\mathrm{BH}_{4}\right)_{4}{ }^{-}$ions. J. Phys. Chem. A. 112 (2008) 7551-7555.

Hagemann, H.; Filinchuk, Y.; Chernyshov, D.; van Beek, W.: Lattice anharmonicity and structural evolution of $\mathrm{LiBH}_{4}$ : an insight from Raman and X-ray diffraction experiments. Phase Trans. 82 (2009) 344-355.

Hagemann, H.; Černý, R.: Synthetic approaches to inorganic borohydrides. Dalton Trans. 39 (2010a) 6006-60012.

Hagemann, H.; d'Anne, V.; Rapin, J. P.; Černý, R.; Filinchuk, Y.; Kim, K. Ch.; Sholl, D.; Parker, S. F.; New fundamental experimental studies on $\alpha-\mathrm{Mg}\left(\mathrm{BH}_{4}\right)_{2}$ and other borohydrides. J. Alloys Compd. (2010b) DOI: 10.1016/j.jallcom.2010.10.068.

Hartman, M. R.; Rush, J. J.; Udovic, T. J.; Bowman, R. C. Jr.; Hwang, S. J.: Structure and vibrational dynamics of isotopically labeled lithium borohydride using neutron diffraction and spectroscopy. J. Solid State Chem. 180 (2007) 1298-1305.

Hauback, B. C.: Structures of aluminium-based light weight hydrides. Z. Kristallogr. 223 (2008) 636-648.

Her, J.-H.; Stephens, P. W.; Gao, Y.; Soloveichik, G. L.; Rijssenbeek, J.; Andrus, M.; Zhao, J.-C.: Structure of unsolvated magnesium borohydride $\mathrm{Mg}\left(\mathrm{BH}_{4}\right)_{2}$. Acta Cryst. B. 63 (2007) 561-568.

International Energy Agency (IEA): World Energy Outlook 2008. OECD/IEA (2008). www.iea.org/books.

Jensen, T. R.; Nielsen, T. K.; Filinchuk, Y.; Jørgensen, J. E.; Cerenius, Y.; Gray, E. MacA.; Webb, C.: Versatile in-situ powder Xray diffraction cells for solid-gas investigations. J. Appl. Cryst. (2010) 43 (2010) DOI: 10.1107/S0021889810038148.

Jin, S.-A.; Shim, J.-H.; Cho, Y. W.; Yi, K. W.; Zabara, O.; Fichtner, M.: Reversible hydrogen storage in $\mathrm{LiBH}_{4}-\mathrm{Al}-\mathrm{LiH}$ composite powder. Scripta Mater. 58 (2008) 963-965.

Johnston, L.; Hallett, N. C.: Low temperature heat capacities of inorganic solids. XIV. Heat capacity of sodium borohydride from 15$300{ }^{\circ}$ K. J. Am. Chem. Soc. 75 (1953) 1467-1468.

Kudo, A.; Miseki, Y.: Heterogeneous photocatalyst materials for water splitting. Chem. Soc. Rev. 38 (2009) 253-278.

Kumar, R. S.; Cornelius, A. L.: Structural transitions in $\mathrm{NaBH}_{4}$ under pressure. Appl. Phys. Lett. 87 (2005) 261916.

Lee, L. Y.; Ravnsbæk, D.; Lee, Y.-S.; Kim, Y.; Cerenius, Y.; Shim, J.-H.; Jensen, T. R.; Hur, N. H.; Cho, Y. W.: Decomposition reactions and reversibility of the $\mathrm{LiBH}_{4}-\mathrm{Ca}\left(\mathrm{BH}_{4}\right)_{2}$ composite. J. Phys. Chem. C 113 (2009) 15080-15086.

Lee, Y.-S.; Shim, J.-H.; Cho, Y. W.: Polymorphism and thermodynamics of $\mathrm{Y}\left(\mathrm{BH}_{4}\right)_{3}$ from first principles. J. Phys. Chem. C 114 (2010) 12833-12837. 
Lee, J. Y.; Lee, Y.-S.; Suh, J. Y.; Shim, J.-H.; Cho, Y. W.: Metal halide doped metal borohydrides for hydrogen storage: The case of $\mathrm{Ca}\left(\mathrm{BH}_{4}\right)_{2}-\mathrm{CaX} 2(\mathrm{X}=\mathrm{F}, \mathrm{Cl})$ mixture. J. Alloys Compd. 506 (2010) 721-727.

Lindemann, I.; Ferrer, R. D.; Dunsch, L.; Filinchuk, Y.; Černý, R.; Hagemann, H.; D'Anna, V.; Lawson Daku, L. M., Latevi M.; Schultz, L.; Gutfleisch, O.: $\mathrm{Al}_{3} \mathrm{Li}_{4}\left(\mathrm{BH}_{4}\right)_{13}$ : a complex double-cation borohydride with a new structure. Chem. Eur. J. 16 (2010) 8707-8712.

Luck, R. L.; Schelter, E. J.: Potassium borohydride. Acta Cryst. C. 55 (1999) IUC9900151.

MacKay, D. JC.: Sustainable energy - without the hot air. Version 3.5.2, UIT Cambridge, Cambridge, 2009. For free: www.withouthotair.com

Mao, J. F.; Guo, Z. P.; Liu H. K.; Yu, X. B.: Reversible hydrogen storage in titanium-catalyzed $\mathrm{LiAlH}_{4}-\mathrm{LiBH}_{4}$ system. J. Alloys Compd. 487 (2009) 434-438.

Marks, T. J.; Kolb, J. R.: Covalent transition metal, lanthanide, and actinide tetrahydroborate complexes. Chem. Rev. 77 (1977) 263293.

Marynick, D. S.; Lipscomb, W. N.: Crystal structure of beryllium borohydride. Inorg. Chem. 11 (1972) 820-823.

Matsuo, M.; Nakamori, Y.; Orimo, S.-I.; Maekawa, H.; Takamura, H.: Lithium superionic conduction in lithium borohydride accompanied by structural transition. Appl. Phys. Lett. 91 (2007) 224103.

Matsuo, M.; Takamura, H.; Maekawa, H.; Li, H.-W.; Orimo, S.-I.: Stabilization of lithium superionic conduction phase and enhancement of conductivity of $\mathrm{LiBH}_{4}$ by $\mathrm{LiCl}$ addition. Appl. Phys. Lett. 94 (2009) 084103.

McCusker, L.B.; Von Dreele, R.B.; Cox, D.E.; Louër, D.; Scardi, P. : Rietveld refinement guidelines. J. Appl. Cryst. 32 (1999) 36-50.

Miwa, K.; Aoki, M.; Noritake, T.; Ohba, N.; Nakamori, Y.; Towata, S.-I.; Züttel, A.; Orimo, S.-i.: Thermodynamical stability of calcium borohydride $\mathrm{Ca}\left(\mathrm{BH}_{4}\right)_{2}$. Phys. Rev. B. 74 (2006) 155122.

Mosegaard, L.; Moeller, B.; Jorgensen, J.-E.; Filinchuk, Y.; Cerenius, Y.; Hanson, J.; Dimasi, E.; Besenbacher, F.; Jensen, T.: Reactivity of $\mathrm{LiBH}_{4}$ : in-situ synchrotron radiation powder X-ray diffraction study. J. Phys. Chem. C. 112 (2008) 1299-1303.

Mozzanica, A.; Bergamaschi, A.; Dinapoli, R.; Gozzo, F.; Heinrich, B.; Kraft, P.; Patterson, B.; Schmitt, B.; Mythen, H.: A 128 channel single photon counting readout chip. Nucl. Inst. Meth. A 607 (2009) 250-252.

Nickels, E. A.; Jones, M. O.; David, W. I. F.; Johnson, S. R.; Lowton, R. L.; Sommariva, M.; Edwards, P. P.: Tuning the decomposition temperature in complex hydrides: synthesis of a mixed alkali metal borohydride. Angew. Chem. Int. Ed. 47 (2008) 2817-2819.

Nielsen, T. K.; Manickam, K.; Hirsher, M.; Besenbacher, F.; Jensen, T. R.: Confinement of $\mathrm{MgH}_{2}$ nanoclusters within nanoporous aerogel scaffold materials. ACS Nano 3 (2009) 3521-3528.

Nielsen, T. K.; Bösenberg, U.; Gosalawit, R.; Dornheim, M.; Cerenius, Y.; Besenbacher, F.; Jensen, T. R.: A reversible nanoconfined chemical reaction, ACS Nano 4 (2010) 3903-3908.

Norby, P.: Hydrothermal conversion of zeolites: an in situ synchrotron X-ray powder diffraction study. J. Am. Chem. Soc. 119 (1997) $5215-5221$.

Orimo, S.-I.; Nakamori, Y.; Eliseo, J. R.; Züttel, A.; Jensen, C. M.: Complex hydrides for hydrogen storage. Chem. Rev. 107 (2007) 4111-4132.

Paskevicius, M.; Sheppard, D. A.; Buckley, C. E.: Thermodynamic changes in mechanochemically synthesized magnesium hydride nanoparticles. J. Am. Chem. Soc. 132 (2010) 5077-5083.

Petit, J. R.; Jouzel, J.; Raynaud, D.; Barkov, N. I.; Barnola, J.-M.; Basile, I. .; Bender, M.; Chappellaz, J.; Davisk, M.; Delaygue, G.; Delmotte, M.; Kotlyakov, V. M.; Legrand, M.; Lipenkov, V. Y.; Lorius, C.; Pepin, L.; Ritz, C.; Saltzmank, E.; Stievenard, M.: Climate and atmospheric history of the past 420,000 years from the Vostok ice core, Antarctica. Nature 399 (1999) 429-436

Pistorius, C. W. F. T.: Melting and polymorphism of $\mathrm{LiBH}_{4}$ to 45 kbar. Z. Phys. Chem. Neue Folge. 88 (1974) 253-263.

Ravnsbæk, D.; Filinchuk, Y.; Cerenius, Y.; Jakobsen, H. J.; Besenbacher, F.; Skibsted, J.; Jensen T. R.: A series of mixed-metal borohydrides. Angew. Chem. Int. Ed. 48 (2009) 6659-6663.
Ravnsbæk, D. B.; Sørensen, L. H.; Filinchuk, Y.; Cerenius, Y.; Jakobsen, H. J.; Besenbacher, F.; Skibsted, J.; Jensen, T.R.: Mixed-anion and mixed-cation borohydride $\mathrm{KZn}\left(\mathrm{BH}_{4}\right) \mathrm{Cl}_{2}$ : synthesis, structure and thermal decomposition. Eur. J. Inorg. Chem. (2010a) $1608-1612$.

Ravnsbæk, D. B.; Brix, M. L.; Filinchuk, Y.; Jensen, T. R.: A novel mixed-cation mixed-anion borohydride $\mathrm{NaY}\left(\mathrm{BH}_{4}\right)_{2} \mathrm{Cl}_{2}$. (2010b) submitted.

Ravnsbæk, D. B.; Filinchuk, Y.; Černý, R.; Ley, M. B.; Haase, D.; Jakobsen, H. J.; Skibsted, J.; Jensen, T. R.: Thermal polymorphism and decomposition of $\mathrm{Y}\left(\mathrm{BH}_{4}\right)_{3}$. Inorg. Chem. 49 (2010c) $3801-3809$

Ravnsbæk, D. B.; Rude, L.; Jensen, T. R.: Chloride substitution in sodium borohydride. (2010d) submitted.

Ravnsbæk, D. B.; Jensen, T. R.: Tuning hydrogen storage properties and reactivity: Investigation of the $\mathrm{LiBH}_{4}-\mathrm{NaAlH}_{4}$ system. J. Phys. Chem. Solids 71 (2010e) 1144-1149.

Reilly, J. J.; Wiswall, R. H.: Formation and properties of iron titanium hydride. Inorg. Chem. 13 (1974) 218-222.

Renaudin, G.; Gomes, S.; Hagemann, H.; Keller, L.; Yvon, K.: Structural and spectroscopic studies on the alkali borohydrides $\mathrm{MBH}_{4}$ $(\mathrm{M}=\mathrm{Na}, \mathrm{K}, \mathrm{Rb}, \mathrm{Cs})$. J. Alloys Compd. 375 (2004) 98-106.

Riktor, M. D.; Sørby, M. H.; Chłopek, K.; Fichtner, M.; Buchter, F.; Züttel, A.; Hauback, B. C.: In situ synchrotron diffraction studies of phase transitions and thermal decomposition of $\mathrm{Mg}\left(\mathrm{BH}_{4}\right)_{2}$ and $\mathrm{Ca}\left(\mathrm{BH}_{4}\right)_{2}$. J. Mater. Chem. 17 (2007) 4939-4942.

Rodríguez-Carvajal, J.: Recent advances in magnetic structure determination by neutron powder diffraction. Physica B. 192 (1993) 55-69. Remark: For a more recent version see: Recent developments of the program FULLPROF. Newsletter of the Commission on Powder Diffraction (IUCr) 26 (2001) 12-19. The complete program and documentation can be obtained at http://www.ill.fr/dif/Soft/fp/

Rude, L. H.; Filinchuk, Y.; Sørby, M.; Hauback, B.; Besenbacher, F.; Jensen, T. R.: Anion substitution in $\mathrm{Ca}\left(\mathrm{BH}_{4}\right)_{2}-\mathrm{CaI}_{2}$ : synthesis, structure and stability of three new compounds. (2010) submitted.

Sato, T.; Miwa, K.; Nakamori, Y.; Ohoyama, K.; Li, H.-W.; Noritake, T.; Aoki, M.; Towata, S.-I.; Orimo, S.-I.: Experimental and computational studies on solvent-free rare-earth metal borohydrides $\mathrm{R}\left(\mathrm{BH}_{4}\right)_{3}(\mathrm{R}=\mathrm{Y}$, Dy, and Gd). Phys. Rev. B. 77 (2008) 104114

Schlesinger, H. I.; Burg, A. B.: Recent developments in the chemistry of the boron hydrides. Chem. Rev 31 (1942) 1-41.

Schlesinger, H. I.; Brown, H. C.; Hyde, E. K: The preparation of other borohydrides by metathetical reactions utilizing the alkali metal borohydrides. J. Am. Chem. Soc. 53 (1953) 209-213.

Shi, Q.; Yu, X.; Feidenhans'l, R.; Vegge, T.: Destabilized $\mathrm{LiBH}_{4}-\mathrm{NaAlH}_{4}$ mixtures doped with titanium based catalysts. J. Phys. Chem. C 112 (2008) 18244-18248.

Skripov, A. V.; Soloninin, A. V.; Babanova, O. A.; Hagemann, H.; Filinchuk, Y. Nuclear magnetic resonance study of reorientational motion in $\alpha-\mathrm{Mg}\left(\mathrm{BH}_{4}\right)_{2}$. J. Phys. Chem. C 114 (2010) 1237012374.

Soulié, J.-P.; Renaudin, G.; Černý, R.; Yvon, K.: Lithium boro-hydride $\mathrm{LiBH}_{4}$. I. Crystal structure. J. Alloys Compd. 346 (2002) 200-205.

Stockmayer, W. H.; Stephenson, C. C.: The nature of the gradual transition in sodium borohydride. J. Chem. Phys. 21 (1953) $1311-1312$.

Sundqvist, B.: Pressure-temperature phase relations in complex hydrides. Solid State Phenomena. 150 (2009) 175-195.

Sundqvist, B.; Andersson, O.: Thermal conductivity and phase diagrams of some potential hydrogen storage materials under pressure. Int. J. Thermophys. 30 (2009) 1118-1129.

Suryanarayana, C.: Mechanical alloying and milling. Progress in Mat. Sci. 46 (2001) 1-184.

Vajo, J. J.; Skeith, S. L.; Mertens, F.: Reversible storage of hydrogen in destabilized $\mathrm{LiBH}_{4}$. J. Phys. Chem. B 109 (2005), 3719-3722.

Züttel, A.; Rentsch, S.; Fisher, P.; Wenger, P.; Sudan, P.; Mauron, Ph.; Emmenegger, Ch.: Hydrogen storage properties of $\mathrm{LiBH}_{4}$. J. Alloys Compd. 356-357 (2003) 515-520. 